\title{
20/40/60. Una reflexió iconotextual de la fotografia com art i ciència
}

\section{Antoni Bover}

Resum

Els 20 simbolitzen l'etapa de la il.lusió, amb la mirada dirigida cap el futur. Els 40 obren l'etapa de la maduresa, amb la consolidació de les primeres il.lusions imaginades des dels 20. Els 60 signifiquen l'etapa de la reflexió, amb l'anàlisi crítica de les petjades que ha deixat marcades la maduresa i el record de les il.lusions dels 20 que encara continuen. Els 20/40/60 no són etapes exactes, depèn de les actituds i de les capacitats d'aprenentatge de cada persona. Aquest article és una anàlisi crítica subjectiva des de la image management i la comunicació visual, i descriu com aquests conceptes han canviat d'una forma exponencial i vertiginosa durant aquests darrers 40 anys. Les capacitats d'anàlisi crítica i d'autoaprenentatge, conjuntament amb la predisposició d'adaptar-se als canvis, permeten gaudir de les etapes professionals i docents, i són unes habilitats vàlides per fer front a les etapes laboral i post-laboral.

\section{Paraules clau}

Art i ciència, comunicació visual, fotografia, image management, disrupció tecnològica

Recepció original: 11 de gener de 2021

Acceptació: 22 de març de 2021

Publicació: 1 de juliol de 2021

\section{El descobriment de la mirada exterior i interior}

La infantesa és l'etapa del descobriment de l'entorn a través de la mirada, l'infant mira i aprèn, essent l'aprenentatge de mirar i fer imatges una de les eines pel desenvolupament de la creativitat. El dibuix i la música, i posteriorment la lectura i l'escriptura, aniran desenvolupant unes capacitats d'aprenentatge de coneixement, que seran les bases per fer front a la joventut i a la maduresa.

Quan es va viure la infantesa i l'adolescència en una etapa educativa franquista, la poca educació cap a la mirada exterior ajudava a propiciar, en alguns casos, el desenvolupament d'una mirada interior que a la llarga va afavorir el desenvolupament de les capacitats d'autoaprenentatge i de la imaginació com una de les habilitats per cercar noves idees.

L'educació visual en l'etapa dictatorial era molt limitada, molt cenyida a uns dibuixos dirigits a imposar les icones del règim i amb unes incipients fotografies en els llibres de text. Mentre que la fotografia com a eina de comunicació visual ja era estudiada en altres països com els Estats Units, Alemanya o França.

Jean A. Keim, I'any 1971 en el seu llibre La photographie et I'homme (Keim, 1971), reflexionava sobre la fotografia des de la perspectiva de la sociologia i la psicologia de la

$\left({ }^{*}\right)$ Doctor UPC, en Comunicació Visual en Arquitectura i Disseny. Llicenciat UB, en Filosofia i Lletres. Professor CITM/UPC Terrassa: Fotografia i CGl, Cultura Visual i Projectes (1994-2020). Professor Col-laborador ETSAB/UPC Barcelona: Fotografia d'Arquitectura (1998-2001). Fundador i coordinador del Laboratori CGI (Computer Generated Imagery) en el CITM/UPC. Terrassa (2005-2015). Director de La Farinera, Centre d'Arts Visuals de Vic (Ajuntament de Vic) (2010-2020). Codirecció de la «Fundació Educació i Art» (Ajuntament de Vic). 2014-2020. Adreça electrònica: antoni.bover@gmail.com 
imatge. Explicava com aquest mitjà fotogràfic s'havia anat introduint en els diferents estaments de la societat i com a partir de l'evolució de la fotografia seria difícil entendre una societat sense imatges.

Cinquanta anys més tard algunes de les seves reflexions han quedat obsoletes, la fotografia ja no forma part d'un grup específic de professionals o de fotògrafs aficionats. A la meitat del segle xx la fotografia s'anava incorporant de forma progressiva a la societat. La incorporació de les càmeres fotogràfiques en les plataformes mòbils, telèfons i tauletes informàtiques, ha significat la democratització definitiva de la fotografia i de la comunicació visual.

Altres reflexions de Keim, com el paper de la fotografia en la comunicació, continuen vigents. En el seu llibre parlava de com la comunicació s'havia transformat en un híbrid entre la imatge i la paraula, entre les imatges i el so.

Els diferents idiomes fan que el llenguatge escrit no sigui un llenguatge universal. El llenguatge visual tampoc ho és, no totes les cultures tenen els mateixos signes icònics i els mateixos valors visuals. Però el sumatori dels signes icònics i dels lingüístics permeten potenciar les capacitats de la comunicació d'idees i de la descripció dels fets psicosocials. El text ajuda a la comprensió de la imatge i aquest text pot anar variant, segons Keim, per adaptar-se a les variacions de la representació iconogràfica al llarg de la història.

Roland Barthes en el seu llibre La Chambre Claire (Barthes, 1980) descrivia que hi han dues maneres d'entendre la història, la d'abans i la de després de la fotografia. La imatge fotogràfica és l'evolució de la pintura realista. En una fotografia, a partir de la captació òptica-mecànica, els retrats i els espais de les escenes històriques estan descrits amb una gran quantitat de detalls visuals.

A l'inici del segle xx, el fotògraf Stieglitz (Frizot, 1998) va ser un dels pioners en descriure que la fotografia no era només una captació òptica-mecànica dels subjectes i dels espais, sinó que tenia un llenguatge visual diferenciat del pictòric, tant en els processos de creació de la imatge com en la forma de transmissió de les emocions de l'autor a l'hora de captar la fotografia. Stieglitz parlava de l'Equivalent, per explicar que en una imatge hi han uns components visuals equivalents que transmeten les emocions del fotògraf $i$, explica que la fotografia no és una pura captació objectiva de la realitat, sinó que en la imatge realitzada hi ha també la mirada subjectiva de l'autor.

El fotògraf Minor White (Fontcuberta, 1984) anava més enllà sobre el terme de l'Equivalent, al descriure que en una fotografia no només hi ha els equivalents de l'autor, sinó també els equivalents de l'espectador de la imatge, i no necessàriament aquests han de coincidir.

Les reflexions d'autors com Keim, Barthes, Stieglitz o White han ajudat a entendre el descobriment de la mirada exterior i interior durant el procés educatiu d'infant i adolescent. Ni aquests autors ni unes reflexions similars estaven en els currículums docents establerts en l'etapa franquista. L'anàlisi crítica del descobriment de la mirada només s'ha pogut fer des del present reflexionant sobre el passat, indagant sobre les emocions i els records que aportaven la visualització de les fotografies de les etapes de la infància. 
II-Iustració 1: Fotografia per al Ilibre de família. Finals dels anys 50 del segle XX. Arxiu familiar

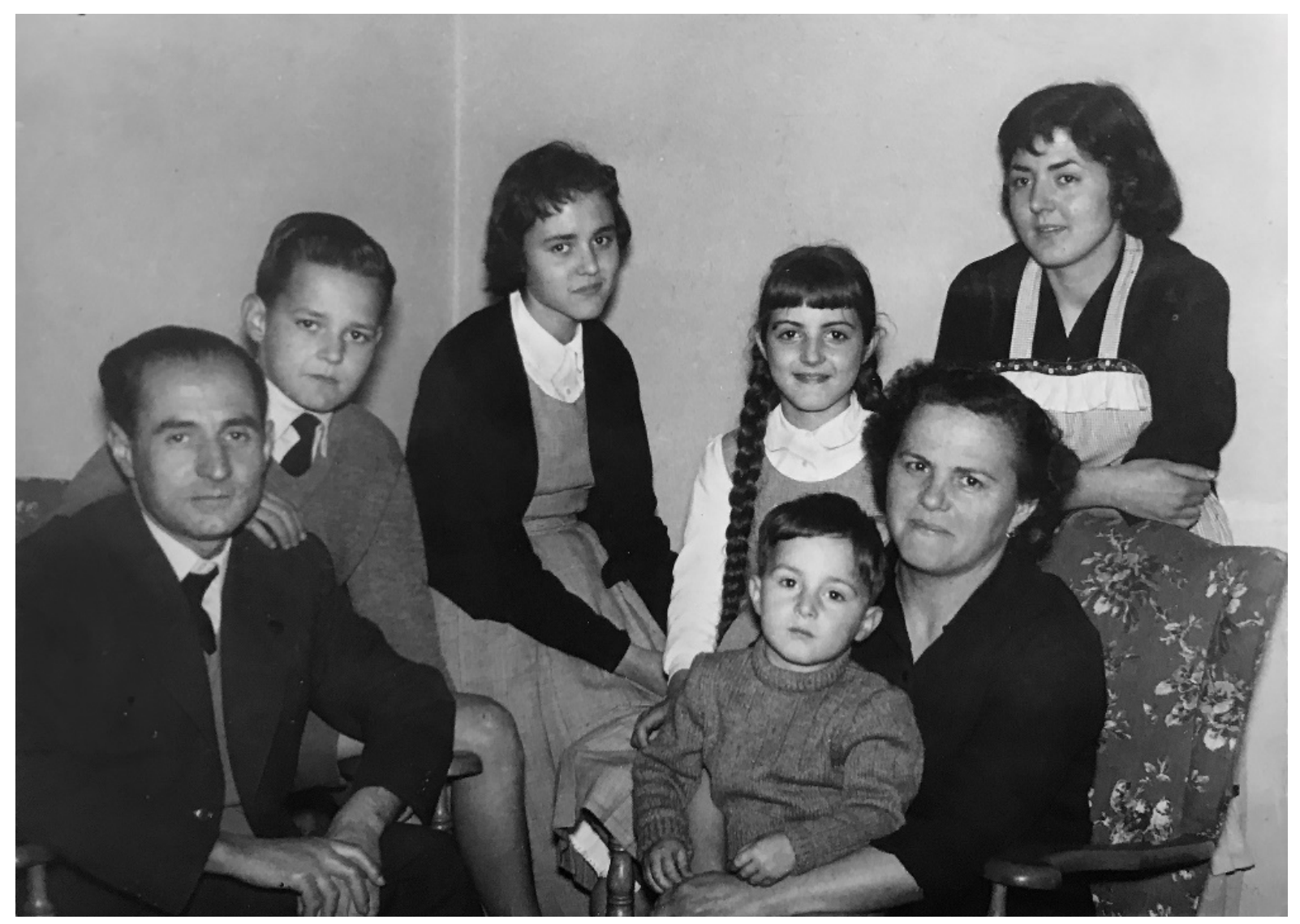

II-Iustració 2: Fotografia grup escolar. Anys 60 del segle xx. Arxiu familiar

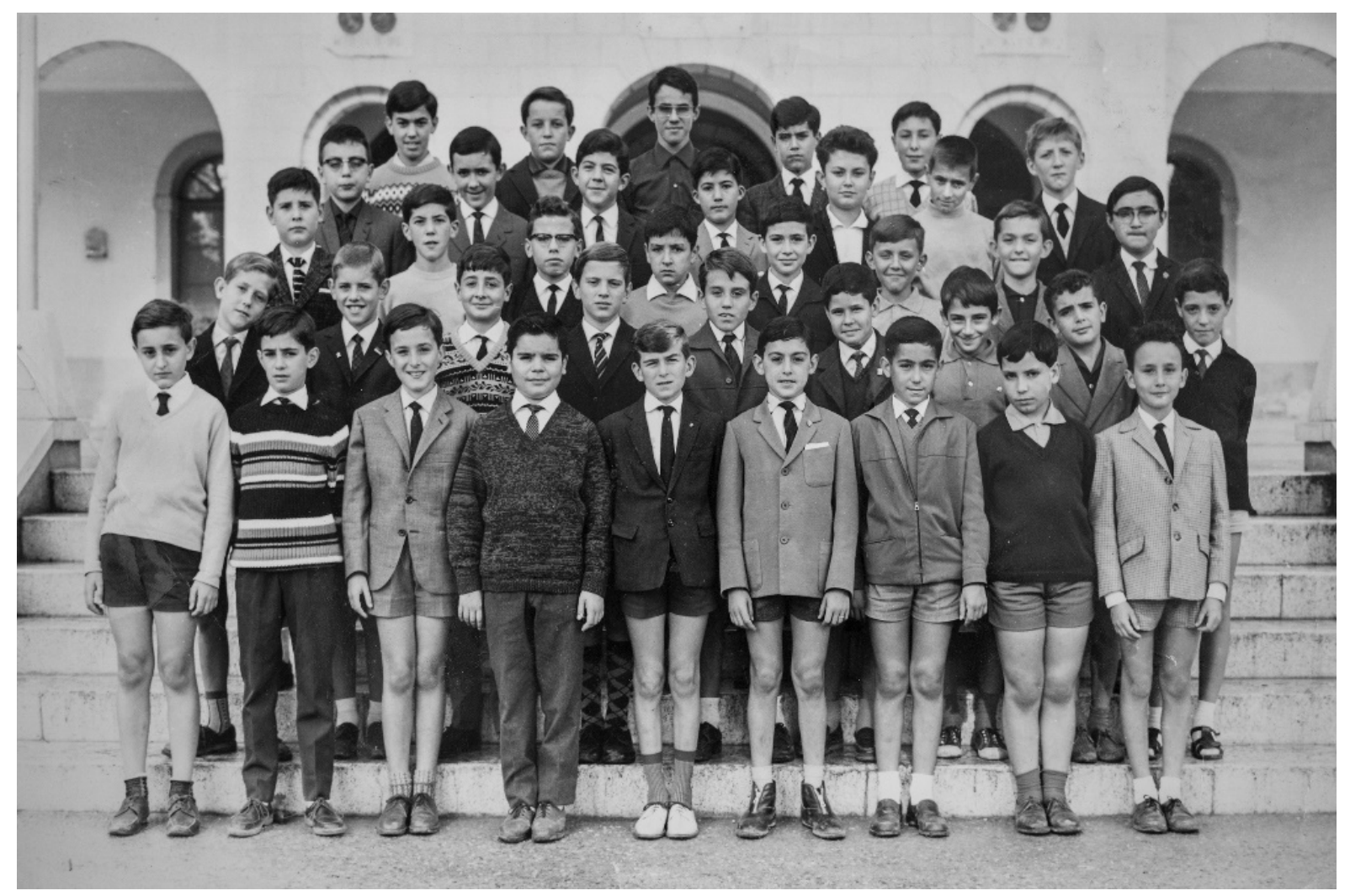


No hi havia hagut cap interès per la fotografia durant la infància, ni s'havia rebut cap informació sobre el potencial de coneixement científic i artístic relacionat amb la imatge. Els primers records sobre la fotografia són un conjunt d'imatges en una capsa de cartró, unes fotografies d'esdeveniments familiars, que de tant en tant es treien per recordar els fets passats. Les il.lustracions 1 i 2 formen part d'aquella capsa d'entreteniments en dies festius.

La il.lustració 1 és una fotografia de la meva família, que mostra un entorn del passat i una família nombrosa i, que jo era el petit de cinc germans. No queda cap record a la memòria del dia de la seva captació, ni de l'espai on es va realitzar. La imatge en si no transmet cap mena d'emoció, més aviat transmet unes emocions i uns records que no queden reflectits en la imatge, i que formen part del procés educatiu i emocional viscut en l'entorn familiar. Fan sorgir a la memòria la bondat dels pares, de les dues germanes grans que eren com dues mares més i de dos germans dels que no hi ha cap record d'aquesta etapa.

La il.lustració 2 és una fotografia del primer any d'internat al Col.legi Valldemia dels Germans Maristes a Mataró, una fotografia de grup de primer de batxillerat. Jo tenia 10 anys i aquesta imatge tampoc aporta a la memòria cap record del dia de la serva captació, si en canvi porta a pensar en alguns dels companys i dels espais viscuts. Però com en el cas de la fotografia familiar anterior, aquesta imatge del col-legi transmet altres records emocionals que no estan reflectits en la fotografia: una disciplina, un ordre, uns silencis estrictes, una política docent lligada amb el càstig. Paradoxalment també fa pensar en la qualitat docent d'alguns dels mestres que no lligava amb les regles estrictes d'un internat religiós.

Mirant la sèrie de televisió The Handmaid's Tale ${ }^{1}$ (El conte de la criada), amb aquelles noies uniformades baixant en silenci per les escales fins arribar al pati, on es posaven de forma ordenada (braç esquerra estirat al costat, braç dret estirat endavant, per crear una quadricula humana), esperant les ordres de la «capitana» per anar a fer les feines de minyona; aquestes escenes visuals porten a la memòria alguns dels moments viscuts en un internat religiós dels anys 60 . Uns nens amb bates d'uniforme, baixant en silenci per les escales cap el pati després d'esmorzar i, posats dins una quadricula estricte, esperant les ordres del «hermano» per anar cap a classe. La ratlla entre la ficció i la realitat, moltes vegades, és molt prima.

La mirada interior, juntament amb l'exterior, és l'element clau pel desenvolupament de la imaginació, de la creació de noves idees en l'etapa de joventut, i per poder preveure des del present les activitats pel futur en l'etapa de la maduresa.

Les fotografies d'etapes viscudes, com les il.lustracions 1 i 2, ajuden a reflexionar sobre el descobriment i l'autoaprenentatge de la mirada interior. Una mirada interior que pot ajudar a sobreviure a un infant en un món d'adults. Quan jo era petit et començaves a plantejar les primeres preguntes davant les coses que no entenies, per sobreviure en un espai familiar d'adults que moltes vegades no era comprensible, i per sobreviure en

(1) HBO. [en línia]: The Handmaid's Tale. Disponible a:<https://es.hboespana.com/series/the-handmaidstale/6575c701-6c3d-4b14-9d98-ba67e102dfa1?gclid=CjwKCAjw0On8BRAgEiwAincsH-

Lov2FqBv4kVX_xdnZbS_7-kwyFEFVcwfKzkvngbxWNU-jW6d5mO7RoCxw0QAvD_BwE\&gclsrc=aw.ds (Data consulta: 21 de desembre de 2020) 
un espai disciplinari contrari als valors intel·lectuals i emocionals del que s'explicava en les aules.

L'aprenentatge i l'autoaprenentatge de la mirada exterior i interior en la infantesa i l'adolescència, són eines de coneixement racionals i emocionals que m'han servit, i poden servir, per entendre la cultura i la comunicació visual.

\section{Els 20, un procés de transició cap a l'aprenentatge racional de la mirada}

Els 20 representen l'etapa de la il.lusió i de la cerca d'idees. Unes il.lusions i unes idees que acompanyen al llarg de la vida. El pas de la infantesa a la joventut és un camí de trencadisses que depèn de cada individu i de cada entorn social, familiar i polític.

Formar part de la darrera generació del curs de pre-universitari, de la darrera promoció de la Llicenciatura de Filosofia i Lletres i del final d'un règim totalitari enmig dels estudis universitaris, són factors que van influir en el pas cap a la maduresa.

Varis autors van influenciar en l'etapa universitària en les primeres cerques en el camp de l'estudi de la filosofia. En el meu cas, destacaria Russell i Ortega y Gasset amb les seves teories sobre el perspectivisme.

Nietzsche i Schopenhauer em van seduir per la seva visió crítica i van propiciar l'interès cap al nihilisme davant unes visions tant diferents i a vegades contradictòries en la forma d'entendre el pensament i la teoria del coneixement.

Un munt de camins i de formes d'entendre la vida, una aporia davant d'alguns professors o entorns socials que volien dirigir els alumnes i joves, mentre que d'altres professors i entorns socials propiciaven que cada alumne o jove fos qui havia de triar la seva opció i el seu camí. Les il.lusions dels 20 i els processos d'aprenentatge d'aquesta etapa, i la gestió de les frustracions quan aquestes no es complien, eren eines per encaminar-se cap al futur.

Els 20 són la mirada cap a una biografia encara no escrita, cap a un munt de coses per descobrir, amb la visió d'altres mirades diferents al que s'ha viscut, i de la caiguda dels primers mites.

Des de la docència universitària, des dels 40 o 60, s'haurien de recordar les il.lusions dels 20 i analitzar i compartir les mirades dels joves que acaben de sortir de l'ensenyament secundari. Uns joves que arriben a la Universitat normalment il.lusionats, a vegades despistats i, moltes vegades, perduts. Un bon moment per transmetre que el més important de l'aprenentatge no està en la informació que es proporciona, sinó en la gestió d'aquesta informació cap els seus interessos personals. On s'ha de mostrar en les activitats diàries en les classes, que el professorat també aprèn a partir de les seves descobertes.

No sempre tothom està d'acord amb una anàlisi crítica sobre la necessitat de la descoberta, tant per la part del professorat com per part de l'alumnat. Fa uns anys un alumne, en un treball sobre la creativitat de la imatge, va reivindicar que a l'hora de fer imatges s'havia de seguir la moda. El debat de la classe va derivar sobre quin era el concepte de la moda i sobre qui havia de decidir què era la moda. Un debat que va derivar cap a uns temes més conceptuals i al sorgiment de preguntes com: ens hem de fer esclaus de les 
directrius dels qui decideixen capitanejar la moda? On queda el concepte de llibertat relacionada amb la creativitat? Perquè no pot ser un alumne qui decideixi que és la moda? Preguntes a vegades difícils de resoldre (o no, perquè son més òbvies del que semblen). $A$ vegades aquestes qüestions serveixen més als altres alumnes, que als mateixos alumnes que han fet propici el debat.

Amb l'evolució de les tecnologies de la informació s'han creat unes noves eines de cerca i, també, un excés d'informació sobre el que es vol aprendre. Això ha comportat que els alumnes puguin trobar més informació sobre les seves il.lusions i d'una manera més ràpida, tant d'un forma individual com grupal, davant d'un ordinador. Aquesta informació no sempre està lligada amb el que s'explica a classe i entendre les seves motivacions és el que s'hauria de tenir en compte alhora d'impartir i preparar les classes, potenciant l'autoaprenentatge i el debat crític.

Un dia un alumne crític va posar en crisi la impartició del coneixement en l'aula. El seu argument era que al Google hi era tot. El debat va derivar cap a la innovació i la cerca de noves idees a partir de l'autoaprenentatge i, que a les xarxes com Google faltava el més important, el coneixement i les reflexions que podien proporcionar elles i ells a les xarxes.

La qüestió sobre la cerca del coneixement ja no depèn de la quantitat d'informació a la que es té accés, sinó a la qualitat i la fiabilitat d'aquesta informació, en saber-la triar i contrastar-la en el mínim de temps.

Les teories relacionades amb el perspectivisme han ajudat a reflexionar sobre com el coneixement es pot estudiar des de diferents punts de vista i perspectives. Des de perspectives individuals o grupals, amb un sumatori de perspectives individuals per obtenir una base de coneixement més àmplia. Però, inclús des de la visió de vàries perspectives, és impossible arribar a l'objectivitat absoluta. A més, també s'han de tenir en compte les diferents visions des de la perspectiva de les diferents etapes de la història, tal com descrivia Ortega y Gasset.

L'aprenentatge a l'aula, I'autoaprenentatge fora d'ella, i els somnis de joventut han de servir per centrar l'interès en unes temàtiques concretes, resoldre les qüestions que vagin sorgint i, encaminar el pas a la maduresa sense perdre les il.lusions dels 20.

En el meu cas, els interessos per les assignatures de matemàtiques i de filosofia en l'educació secundària van anar derivant cap a l'interès per la semiòtica de la imatge en l'educació superior. Descobrir la fotografia als 20 va permetre entrar en una matèria de coneixement desconeguda i comprovar, a vegades, que era poc apreciada en el món acadèmic. La semiòtica era un àmbit d'estudi destinat principalment a la lingüística, però s'anava incorporant i relacionant amb altres temàtiques de coneixement, com per exemple la de la imatge. L'ampliació d'estudis a la Universitat Paris VIII, va permetre assistir a I'assignatura de Semiòtica de la Fotografia, que no s'impartia cap a la Universitat de Barcelona.

El fotògraf francès Henri Cartier-Bresson descrivia, als anys trenta del segle Xx, el concepte d'instant decisiu, com aquell instant en què en el moment de prémer el botó de la càmera, els elements de la imatge devien estar ordenats estèticament dins la composició de la fotografia.

Uns anys més tard als EEUU, el fotògraf Robert Frank anava més enllà de l'instant decisiu i tenia més interès per un instant significatiu, en què en el moment de prémer el botó 
de la càmera els elements de la imatge havien d'estar distribuïts per transmetre un significat, un concepte $\mathrm{o}$, una metàfora.

No serà fins als anys 70 als Estats Units d'Amèrica en què una corrent de fotògrafs, per alguns representants de la fotografia filosòfica, van voler trencar els límits dels conceptes d'instants decisius o significatius. El fotògraf Ralph Gibson, per exemple, recolzava la idea que les imatges no tenien cap més valor que els hi volia donar l'autor o els espectadors de les fotografies.

II-Iustració 3: Des del carrer. Toni Bover. Anys 70 del segle xx

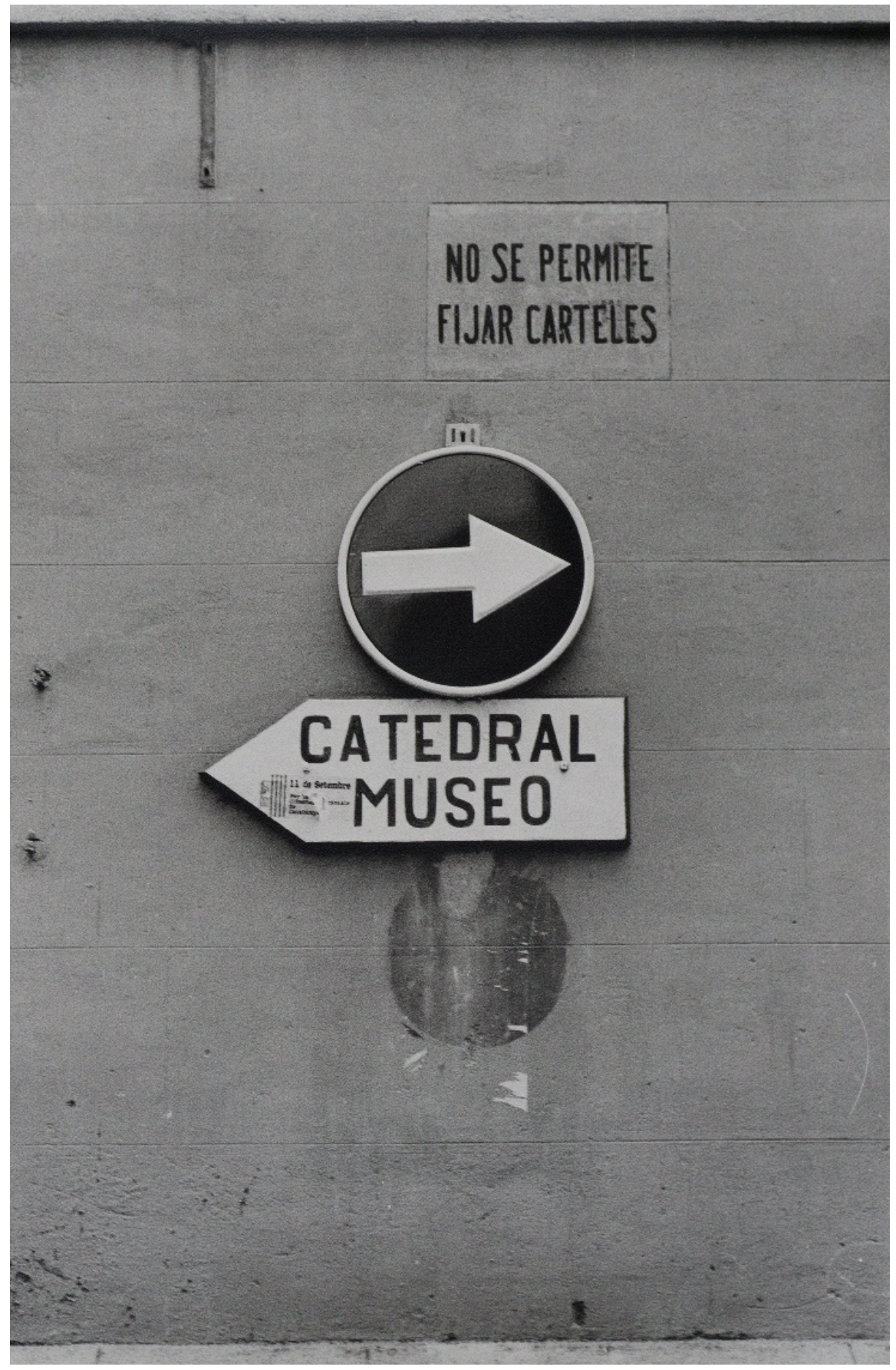




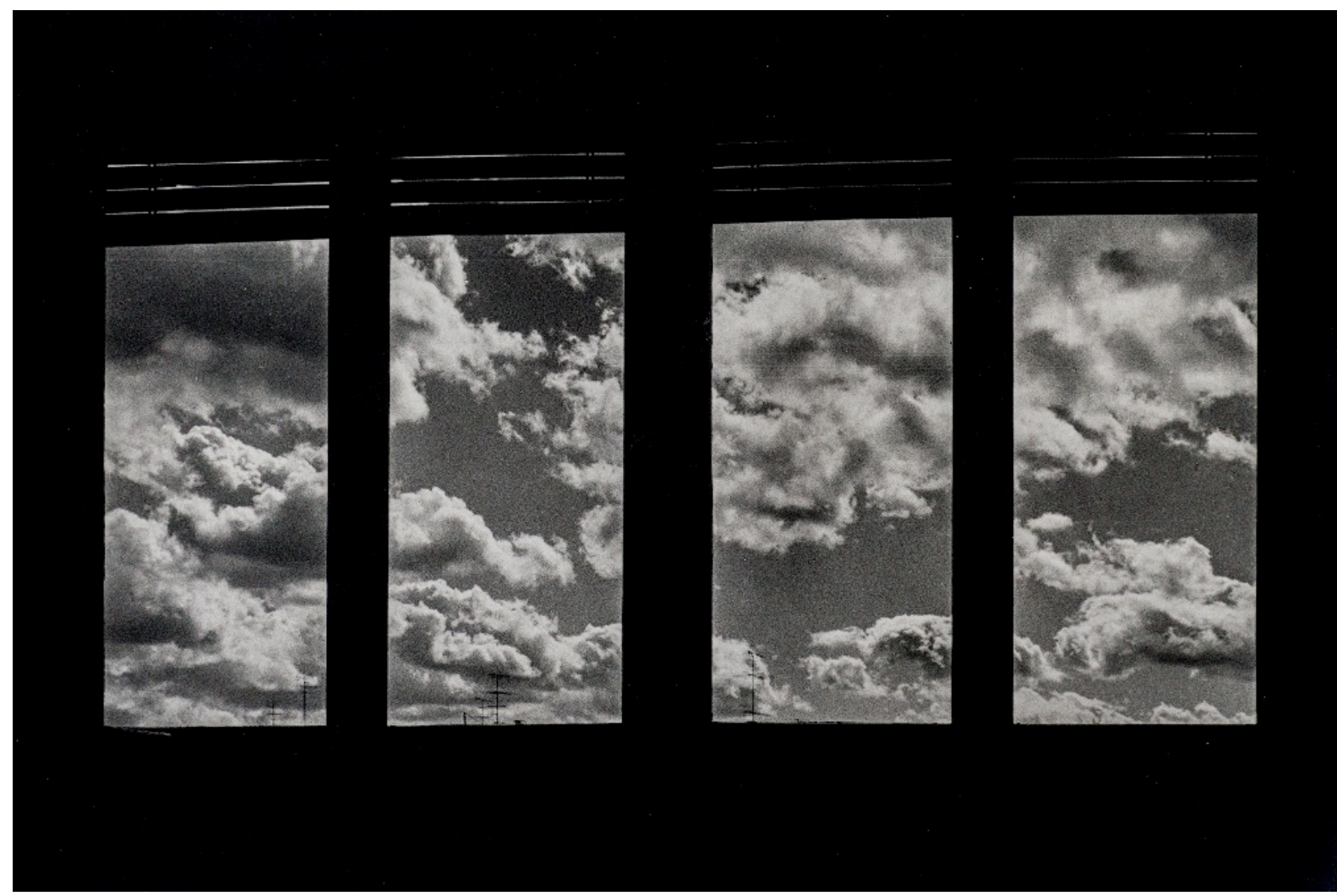

És en aquesta etapa de reflexió i d'estudiant, i amb les il.lusions per a l'aprenentatge de la fotografia i de la semiòtica visual, quan vaig realitzar les il.lustracions 3 i 4 que es posen com a exemple.

Vaig començar estudiar fotografia per l'atracció que em va proporcionar, I'any 1975, una exposició de fotografia filosòfica a la desapareguda galeria Spectrum a Barcelona. En aquelles dates jo no tenia ni càmera ni cap coneixement sobre l'àmbit de la fotografia. La il.lustració 3 és una fotografia realitzada al final del franquisme, una de les primeres imatges realitzades en l'etapa d'estudiant; per entendre el concepte del signe icònic i la relació entre el significant i el significat com elements del llenguatge visual. Una fotografia amb una metàfora visual que mostra les contradiccions de les informacions i de les obligacions, amb els indicadors de catedral i museu com elements culturals, i en direcció contrària la senyal de trànsit de direcció obligatòria. Sobre aquests indicadors, un text amb la prohibició explícita d'enganxar cartells. Aquesta imatge transmetia les contradiccions a les què els joves estaven -i encara estan- sotmesos, entre els somnis d'una incipient joventut i amb ganes de futur, i les sensacions de tenir davant un món d'adults que semblen que hagin oblidat la importància de tenir il.lusions.

La imatge dels núvols m'ha acompanyat al llarg de la vida, és la imatge d'un element real, canviant i aleatori. Una forma visual diferent que s'escapa de la reiteració. La il.lustració 4 és una imatge fotogràfica realitzada per transmetre amb una metàfora visual, la necessitat de cercar quelcom nou, de pensar que darrera de la comoditat i de la seguretat dels coneixements apresos, també hi ha ganes de descobrir el que encara no es coneix.

El núvol és una forma estètica, real i abstracta al mateix temps, que només té significat si l'espectador del núvol o de la seva imatge li vol donar. I si es vol, pot transmetre les emocions procedents de la mirada interior (els Equivalents dels què parlava Stieglitz) o la bellesa de les formes que capta la mirada exterior. 
Familiaritzar-me amb la fotografia em va permetre aprendre a mirar, comunicar idees a partir dels signes icònics i ordenar els elements d'una imatge per entendre les bases de l'estètica i de la comunicació visual.

\section{Els 40, un procés de transició cap a la maduresa. La mirada cap al futur des del present}

Els 40 obren l'etapa de la maduresa i de la millora continua, s'agafa consciència del que s'estima i es consoliden les idees dels 20. Aquesta etapa em va servir per entendre i consolidar, els coneixements sobre la fotografia i la seva relació amb la comunicació visual.

La inquietud per entendre la fotografia des de la semiòtica de la imatge es va veure estroncada, ja que els conceptes de semiòtica aplicats principalment a la lingüística no servien per estudiar la fotografia. Un dels principals objectius era entendre la fotografia com un element de reflexió, més enllà d'uns sectors professionals o artístics, uns sectors amb unes visions parcials de la matèria que només s'emmirallaven en la seva especialitat. Amb poca informació sobre la recerca de coneixement en la matèria de fotografia en l'àmbit educatiu, moltes preguntes quedaven per resoldre, i no totes han quedat resoltes en el pas del temps i en l'aprenentatge al llarg de la vida.

- Per què la fotografia ha estat considerada durant molt anys com un element mecànic o purament tècnic, si també pot transmetre emocions tant per part de l'autor com per part dels espectadors que visualitzen la imatge?

El poeta francès Baudelaire (Sougez, 1981) va ser un dels detractors de la fotografia en els seus inicis, a principis del segle XIX. Per ell la fotografia significava la mort de l'art, ja que era una captació mecànica de la realitat. Baudelaire és un poeta universal amb la seva obra literària, el seu llibre Les Fleurs du Mal ha estat i és encara un Ilibre de capçalera per molts, però la seva visió sobre la fotografia es devia a la falta de perspectiva sobre el coneixement d'aquest mitjà. Baudelaire va ser fotografiat per un dels pioners de la fotografia de retrat a França, Gaspard-Félix Tournachon, més conegut com a Nadar. Algunes de les seves fotografies les podem veure en les portades de llibres de Baudelaire, en les edicions de Les Flors del Mal (Baudelaire, 1990) i Els Petits poemes en prosa (Baudelaire, 1991), de la col-lecció Edhasa Clàssics Moderns. Aquestes dues fotografies, dos retrats del poeta, són un exemple del subjectivisme en la captació de les imatges fotogràfiques, tant en la composició com en la posició del punt de vista del fotògraf respecte la posició de personatge, i en l'instant de captació de la mirada del poeta. Dues imatges que mostren que darrera d'una captació fotomecànica i un procés fotoquímic, hi ha un autor que transmet un punt humà a la imatge resultant. El pintor Delacroix pensava tot el contrari de Baudelaire, ja que molts dels pioners de la fotografia venien del camp del dibuix i la pintura.

A Anglaterra, William Fox Talbot, un dels descobridors de la fotografia en paral.lel a Daguerre a França, descrivia en un dels seus escrits com quedava fascinat davant les primeres fotografies, al comprovar com les línies de la composició de la imatge sortien totes de cop i no s'havien de fer una darrera l'altra com en el cas del dibuix (Fontcuberta, 1984). Talbot coneixia bé el dibuix ja que va recórrer l'Europa clàssica dibuixant, amb la càmera lúcida, els paisatges urbans i els patrimonis històrics, com un dels participants de Le Grand Tour (Zannier, 1987).

La història de la fotografia, durant el segle XIX, mostra principalment una millora en els processos fotoquímics i una millora en la qualitat de les càmeres i de les òptiques. Serà 
a partir del segle $\mathrm{xx}$, que la fotografia avança com una eina de comunicació des d'una perspectiva psicosocial.

Lewis Hine (Lemagny i Rouillé, 1986) a principis del segle xxals Estats Units, per exemple, va utilitzar les imatges com a mitjà de conscienciació social d'un dels problemes més greus de la revolució industrial: I'explotació infantil. Hine va fotografiar diferents indústries on es podien veure uns nens treballant a les mines i d'uns nenes en les fàbriques tèxtils. L'impacte emocional de les seves fotografies va contribuir a què es fessin lleis relacionades amb la seguretat laboral, o l'explotació infantil.

Als anys 30, el grup de fotògrafs de la Farm Security Administration (F.S.A.) ${ }^{2}$ va recórrer les zones més perjudicades pel Crash de 1929 als Estats Units, visualitzant els espais empobrits i la tristesa de les mirades dels seus habitants. Algunes d'aquestes fotografies han quedat com a imatges-mites en la història de la fotografia i de la comunicació visual.

Als anys 60, la fotògrafa estatunidenca Diane Arbus recorria Nova York per seleccionar els personatges que volia retratar, l'amargor que transmeten les seves imatges és un reflex del seu interior que la va portar a acabar amb la seva vida.

Baudelaire en un dels seus petits poemes en prosa, L'étranger, parlava d'un home que estimava els núvols. Si hagués viscut més anys, hauria vist que la fotografia, també, permet la captació de la metàfora visual a través de la mirada cap els petits núvols.

- Per què la fotografia va tardar tants anys en ser considerada un gènere artístic, quan el cinema basat en els principis de la fotografia va ser considerat el setè art des dels seus inicis?

La principal diferència entre la fotografia i el cinema és la incorporació de la dimensió del temps associada a l'enquadrament d'una imatge en dues dimensions (tres dimensions amb la disposició dels components de la imatge en perspectiva dins la composició). El control del temps en la visualització de les imatges captades dins una càmera fosca, va permetre incidir en el control de les emocions dels espectadors des de les primeres pel.lícules. El film dels germans Lumière de I'any 1895, L'Arrivé d'un train en gare de La Ciotat, està considerat un dels films pioners en el llenguatge cinematogràfic. En la pel.lícula es visualitza la imatge d'un tren en perspectiva que des de la llunyania va avançant en direcció a la càmera. Aquesta arribada de la imatge del tren cap a l'espectador era una manera de visualitzar la realitat totalment desconeguda, i sembla que alguns dels primers espectadors del film es van aixecar, sobtadament, de la cadira amb la sensació que el tren se'ls tirava a sobre.

La fotografia i el cinema són productes de la revolució industrial, neixen en l'àmbit de la ciutat i com en la majoria de les aportacions de la revolució industrial desperten d'entrada més interès en els enginyers i en els empresaris que en els professionals de les ciències humanes. El cinema serà un cas a part de la fotografia per la incidència econòmica del control de les emocions, al convertir la visualització de les imatges cinematogràfiques en un espectacle i en un negoci lucratiu.

(2) Centre National de la Photographie (ed.) (1983) Amérique. Les années noires: F.S.A 1935-1942. Paris, Collection Photo Poche. 
La fotografia i el cinema són productes de la recerca científica. El cinema neix a partir dels estudis sobre la persistència retinal que explica que les imatges que es visualitzen, en els òrgans de visió humans, es mantenen unes fraccions de segon després que hagi desaparegut l'estímul. L'aplicació d'aquests coneixements a la càmera fotogràfica va permetre mostrar el moviment i el control de la dimensió del temps en la comunicació visual.

Els conceptes de moviment i de control del temps en la fotografia no es van aplicar només en cinema. Alguns processos, com per exemple, la cronofotografia o la multi-exposició en una sola imatge, com en el cas de les fotografies de Marey, van contribuir a noves formes d'entendre la relació moviment-temps en la comunicació visual. Posteriorment alguns pintors, com per exemple Duchamp o Giacomo Balla, van utilitzar aquestes recerques visuals en les seves obres pictòriques (Scharf, 1994). Una de les paradoxes de la història de l'art és veure com la pintura a partir de la fotografia derivava cap a l'impressionisme (per a una captació ràpida de la imatge) i cap a l'abstracció (influenciats alguns pintors davant la visió del món que proporcionaven les foto-macrografies i les vistes aèries). En contraposició, alguns fotògrafs pretenien ser considerats artistes i modificaven les seves imatges amb processos químics per imitar la pintura impressionista, mentre que altres cercaven l'abstracció captant uns fragments descontextualitzats de la realitat.

Aquesta dualitat conceptual art-tècnica de la fotografia, encara, no està del tot resolta. De totes maneres és obvi, en l'actualitat, que els processos fotogràfics són unes eines utilitzades tant per l'expressió artística com per la divulgació visual de temes socials i científics.

- Per què la fotografia no ha estat considerada un element d'interès en l'educació, mentre els llibres de text estan plens d'imatges per il.lustrar els textos i els continguts relacionats amb la comunicació formen part dels currículums escolars?

Pel que respecta a l'ensenyament de la fotografia, no tots els països i les institucions culturals I'han tractat amb el mateix interès. L'ensenyament de la fotografia entra a la Universitat, als Estats Units, a principis del segle Xx. Als anys 30 des de la Bauhaus alemanya, un dels seus professors i artista Moholy-Nagy, avançava que els «analfabets» del demà serien els que no sabrien ni llegir ni escriure, ni fer ni entendre les imatges fotogràfiques.

A l'estat espanyol no seria fins l'any 1994 que la Universitat Politècnica de Catalunya (UPC) impartiria el primer Grau en Fotografia com a títol propi i aquesta titulació no seria oficial fins a principis del segle XXI. Des del 2015 es desprograma aquesta titulació a la UPC davant dels canvis evolutius de la fotografia i es substitueix pel Grau Disseny, Animació i Art Digital més relacionat amb les temàtiques d'Image Management ${ }^{3}$.

Una de les paradoxes en l'àmbit de l'educació, ha estat veure l'increment exponencial de les imatges fotogràfiques, com a suport visual de les temàtiques impartides en les classes magistrals, i la seva utilització en els llibres de text; mentre el coneixement de la imatge fotogràfica queda reduït a les activitats extraescolars.

(3) "Puedo aventurar que en el futuro no habrá estos compartimentos de "fotógrafo", "videasta", etc., sino que hablaremos de image managers, es decir, comunicadores y creadores de imágenes; en el futuro daremos cursos de image management» (Fragment de l'entrevista a Nathan Lyons) (Fontcuberta, 1990, p. 15). 
Durant l'etapa de la fotografia fotoquímica i en el inicis de la imatge electrònica, els equipaments específics (aparells de captació i processos de laboratori) tenien un cost econòmic que no tots els centres escolars es podien permetre. Però la manca de recursos econòmics, no hauria estat la única causa per a no impartir més coneixements de fotografia en els currículums docents. La consideració de la fotografia com una captació purament òptica-mecànica de la realitat, per alguns, i la manca de coneixements sobre les implicacions emocionals en la captació de fotografies, per uns altres; serien algunes de les causes per no haver utilitzat la fotografia, com a matèria de coneixement, en la majoria dels centres escolars

Un dels objectius més apassionants pel personal docent és la recerca, i la millora dels coneixements en les matèries a impartir. Haver pogut treballar en temes docents relacionats amb la fotografia, amb alumnes d'edats diferents i en uns espais educatius diferenciats, va permetre des dels anys 80 veure com l'aprenentatge visual era més àgil i més efectiu com més joves era l'alumnat. En activitats d'aprenentatge de fotografia per a infants i per a adults, les imatges resultants d'exercicis semblants realitzats a classe eren millors - tant des del punt de vista de la semiòtica com de l'estètica o de la tècnica-en els alumnes més joves que en els més grans.

L'interès i l'aprenentatge més ràpid en els joves respecte als més grans, s'ha mantingut al llarg de l'evolució en els processos de captació d'imatges i les seves aplicacions en la comunicació visual. Com més vertiginosa i més exponencial ha estat aquesta evolució, més ha anat i va creixent aquest distanciament d'aprenentatge o autoaprenentatge generacional.

Des d'una perspectiva històrica, també es pot apreciar que la fotografia des d'un punt de vista social i artístic va ser més acceptada i va evolucionar més ràpidament als Estats Units que en la majoria de països europeus. El conservadorisme cultural de la vella Europa va tenir menys influència en un país jove com els Estats Units.

La capacitat de conviure amb la incertesa i la capacitat d'adaptabilitat davant l'evolució de la tecnologia i de les seves aplicacions socials van ser per mi un dels gran reptes de la maduresa.

Des del present s'ha de fer front a una mirada de futur, i quan més es puguin acotar les qüestions que vagin sorgint, més possibilitats hi haurà de resoldre dubtes en el demà.

Aquesta etapa dels 40 em va servir per entendre les bases de la fotografia, per comprovar que aquesta només es pot explicar des de les relacions entre l'art i la ciència, des de les relacions entre la imatge fixa i la imatge en moviment, des de la mirada exterior i interior, des d'una visió intergeneracional i intercultural, i que s'hauria d'aplicar més en l'àmbit educatiu.

L'aprenentatge de la fotografia és el coneixement de la semiòtica i de la comunicació visual i, que es pot aprendre i aplicar en diferents àmbits del coneixement. Per entendre la fotografia es necessiten coneixements relacionats amb les humanitats, amb la física per entendre les característiques de la llum i les seves repercussions sobre els objectes, amb la tecnologia per entendre el domini dels aparells i dels processos de formació de la imatge, amb la geometria per entendre les lleis de la perspectiva i amb els càlculs matemàtics per comprendre les estructures numèriques dels processos que hi intervenen. 
Si en l'escriptura són necessàries unes estructures lingüístiques per fer comprensiu el contingut d'una frase, la fotografia necessita el coneixement d'unes estructures físicamatemàtiques per fer comprensiu el contingut de la imatge.

Per entendre la comunicació visual és necessari la comprensió de la relació espaitemps, la utilització del binomi imatge-paraula i saber interrelacionar diferents tècniques, o processos, de creació d'imatges.

Scott McCloud, en el seu llibre Entender el Cómic (2014), defineix el còmic com unes II. Iustracions juxtaposades i altres imatges en seqüència deliberada, amb el propòsit de transmetre informació i obtenir una resposta estètica del lector. El còmic és un gènere de la comunicació visual, que treballa la dimensió del temps i la narrativa visual amb precedents històrics tant en l'art egipci com en l'art maia.

En la fotografia hi ha autors de referència que utilitzen la narrativa i les seqüències visuals, com per exemple el fotògraf americà Duane Michals (Centre National de la Photographie, 1983b). Michals, a partir dels anys 70, va realitzar fotografies seqüencials dins l'anomenada fotografia filosòfica. Unes sèries amb una metàfora visual, relacionada tant amb l'estètica fotogràfica com amb la dimensió del temps.

\section{II-Iustració 5: Imatge seqüencial. Toni Bover. Anys 90 del segle xx}
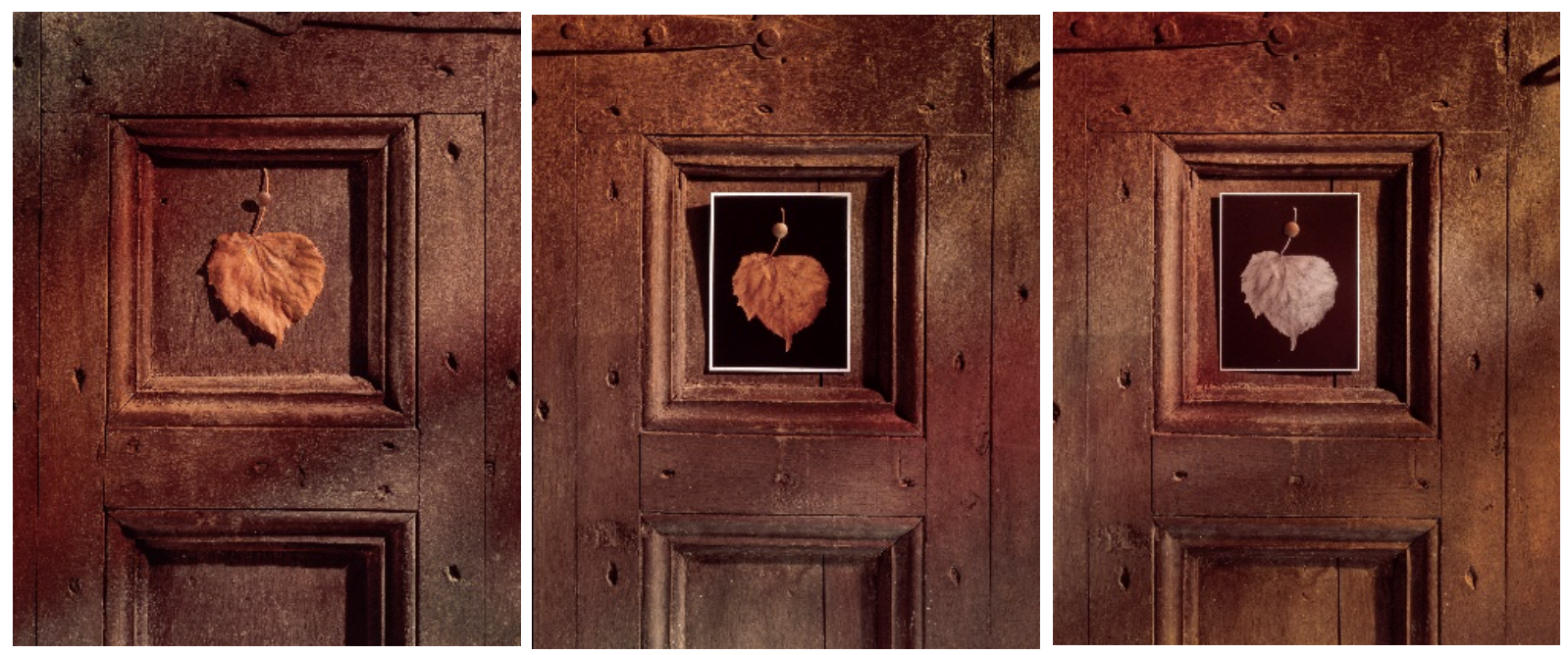

La sèrie d'imatges de la il.lustració 5 formen part de l'inici de la meva etapa de maduresa, amb la recerca dels elements essencials en la creació d'una imatge fotogràfica, com el sumatori de les bases icono-comunicatives de la metàfora visual amb les bases físiquesnumèriques de la il.luminació, per mostrar visualment el contingut d'una idea.

L'arbre transformat en una porta i la fulla com a element residual d'aquest arbre, que anirà desapareixent en el temps, i només quedarà el seu record en la fotografia. Una fotografia que també s'anirà degradant, començant amb la degradació dels colors. Tempus Fugit on només queden els records i en el temps aquests també es van diluint.

La direcció i la qualitat de la llum descriuen les formes, els volums i els colors. Uns valors d'intensitat i de tons de colors que calia mesurar numèricament per una correcta captació en un suport fotoquímic.

La seqüència d'imatges esdevé una reflexió visual sobre les dimensions espai-temps, una imatge plana de dues dimensions, que esdevé tridimensional a partir de la geometria 
de la perspectiva i de la distribució de les llums i les ombres en la composició. La seqüència serial aporta la quarta dimensió, la dimensió del temps, amb la lectura de les imatges una darrera de l'altra.

El creixement personal no és només l'adquisició de més coneixements, és també la capacitat d'adaptar-se als canvis. L'evolució de la tecnologia amb la irrupció de la informàtica ha aportat unes altres eines per a l'adquisició i la impartició de matèries docents.

L'evolució, o revolució, informàtica i digital connota una rapidesa d'aprenentatge en l'adquisició de nous coneixements tecnològics. Els més joves s'adapten més fàcilment als canvis que les franges d'edat posteriors.

Aquestes diferències d'habilitats intergeneracionals eren normals en el camp de l'esport, però no eren habituals en altres àmbits. Aquesta disrupció tecnològica va comportar i comporta noves preguntes per resoldre.

- Per què hi ha encara aquesta separació entre la ciència i la tecnologia, i els coneixements humanístics i l'art?

La recerca en ciència i tecnologia ha estat realitzada des de sempre per un conjunt de dones i homes que han estudiat la natura, les seves lleis i els processos evolutius, amb l'ajuda de l'abstracció matemàtica, i amb l'estudi de la seva utilitat per a la societat. Alguns àmbits de l'anomenat humanisme, i de les activitats artístiques, s'han volgut allunyar de la racionalitat de les ciències i de les enginyeries, com si aquestes no formessin part de l'humanisme. Aquestes separacions de coneixements han comportat, masses vegades, unes reflexions psicosocials i psicopedagògiques allunyades de l'evolució tecnològica. La separació entre les ciències i les lletres durant molt anys en l'educació, seria un exemple.

L'evolució exponencial de la tecnologia ha comportat més que mai que les ciències humanístiques depenguin de les eines tecnològiques per a l'adquisició i la divulgació del coneixement, i que els híbrids imatge i paraula, imatges i so, siguin eines necessàries per a l'aprenentatge a les aules i l'autoaprenentatge individual .

L'equívoc de considerar com a conceptes separats l'humanisme i la ciència el descrivia John Brockman en el seu llibre La tercera cultura (Brockman, 1996), quan feia referència a la conferència de C.P. Snow, de l'any 1959, on explicava l'error de separar les «dues cultures» i la incredulitat que representa no aplicar el terme humanista als texts científics o tecnològics.

- Per què no incorporar més les habilitats d'aprenentatge dels 20, i admetre davant dels més joves que les limitacions dels 40 no són un problema?

Actualment la maduresa comporta entendre que un jove pugui tenir, a vegades, uns coneixements i unes habilitats d'aprenentatge millors que les dels adults. Aquest fet no hauria de comportar cap problema, ans tot el contrari, el professor no ha de ser sempre I'únic element d'impartició de coneixement a l'aula. La humilitat d'un professor sempre aportarà més acceptació davant dels alumnes que la prepotència. Aquesta actitud comportarà que el coneixement que pot aportar el professorat des de la maduresa arribi millor als alumnes. 
Els excessos de coneixements, la facilitat d'accedir-hi, i la necessitat d'especialització en matèries concretes, consolida la importància dels equips interprofessionals; al relacionar altres especialitats de coneixement amb les que no són pròpies.

La capacitat d'adquisició ràpida de coneixements tecnològics comporta la consolidació dels equips intergeneracionals. El sumatori d'equips interprofessionals i intergeneracionals en la gestió de projectes, millora en escreix els resultats obtinguts en aquests projectes.

Si un alumne és més ràpid que el mateix professor en determinades habilitats, que són necessàries en el desenvolupament d'un projecte; el professor no ha de competir amb ell, ha de treballar conjuntament amb ell per millorar i enriquir intel-lectualment els resultats que es volen obtenir. El project base learning és un procés d'aprenentatge més per a la consolidació de coneixements en les aules.

\section{- Per què davant la democratització definitiva de la fotografia, encara es treballen poc els} fonaments d'aquesta eina de comunicació en l'educació?

La fotografia és l'evolució dels aparells de perspectiva que es van desenvolupar i millorar a partir del Renaixement. L'any 1550, el físic Girolamo Cardano (Gernsheim, 1967) incorporava una lent biconvexa a la càmera fosca. L'any 1568, Danielle Barbaro (Gernsheim, 1967) descrivia la incorporació d'uns diafragmes de diferents mides, conjuntament amb l'òptica, per tenir una imatge més nítida dins l'interior de la càmera fosca que s'utilitzava per dibuixar.

L'evolució dels estudis químics sobre l'ennegriment dels materials sensibles a la llum a partir del segle XVII, conjuntament amb els canvis socials del segle XVIII, propiciarien el naixement de la fotografia al segle XIX. Diferents emprenedors com Niepce, Daguerre, Talbot o Bayard van descobrir la incorporació de materials sensibles a la llum a l'interior de la càmera fosca, que utilitzaven per dibuixar. Amb el naixement de la fotografia creaven una nova eina de comunicació visual per al futur.

La fotografia és una matèria singular que està relacionada amb diferents continguts del currículum escolar: I'aprenentatge de la mirada (principalment temes relacionats amb creativitat artística), els continguts d'història i ciències socials (utilització de la imatge com a suport al text), els continguts de química (processos fotogràfics analògics) i de física (principalment temes relacionats amb la llum), els continguts de tecnologia (l'òptica i la mecànica), els continguts de matemàtiques (em temes com la geometria de la perspectiva i les proporcions numèriques) i la comunicació (emissors i receptors d'informació).

L'evolució de la fotografia fotoquímica a la imatge digital és un canvi important respecte la innovació i la cerca de noves aplicacions dels coneixements de la fotografia en l'educació. La captació electrònica de la imatge d'allò real, transformada a uns valors numèrics, comporta que a partir de valors numèrics es poden crear imatges realistes, d'elements que no existeixen, en un ordinador. La incorporació de les matemàtiques en la creació d'imatges, permet recrear simulacions iconogràfiques d'estètica realista, tant per representar el passat com el futur.

El CGI (Computer Generated Image) consisteix en crear imatges generades per ordinador, fotografies virtuals realitzades amb càmeres i fonts d'il.luminació a partir de valors 
numèrics en un programari d'ordinador. La imatge generada per ordinador de tipus realista està basada en els mateixos principis que els necessaris per captar una imatge d'un espai real en una càmera fotogràfica. Els valors numèrics relacionats amb l'òptica, amb els components mecànics d'una càmera, amb els paràmetres de la llum i la il.luminació, o amb els processos de postproducció d'imatges, es poden simular amb precisió mitjançant els programaris i les eines informàtiques.

La fusió d'imatges del real i del virtual, també permeten il.luminar la imatge virtual a partir dels valors numèrics d'una imatge, amb perspectiva cilíndrica, generada a partir de fotografies; amb el procés anomenat Image Based Lighting (IBL) o la il-luminació a través de fotografies (Bover, 2011).

\section{II·Iustració 6: Imatge seqüencial, amb fusió d'imatges fotogràfiques i CGI. Toni Bover i Mi- quel Bigas. 2009}
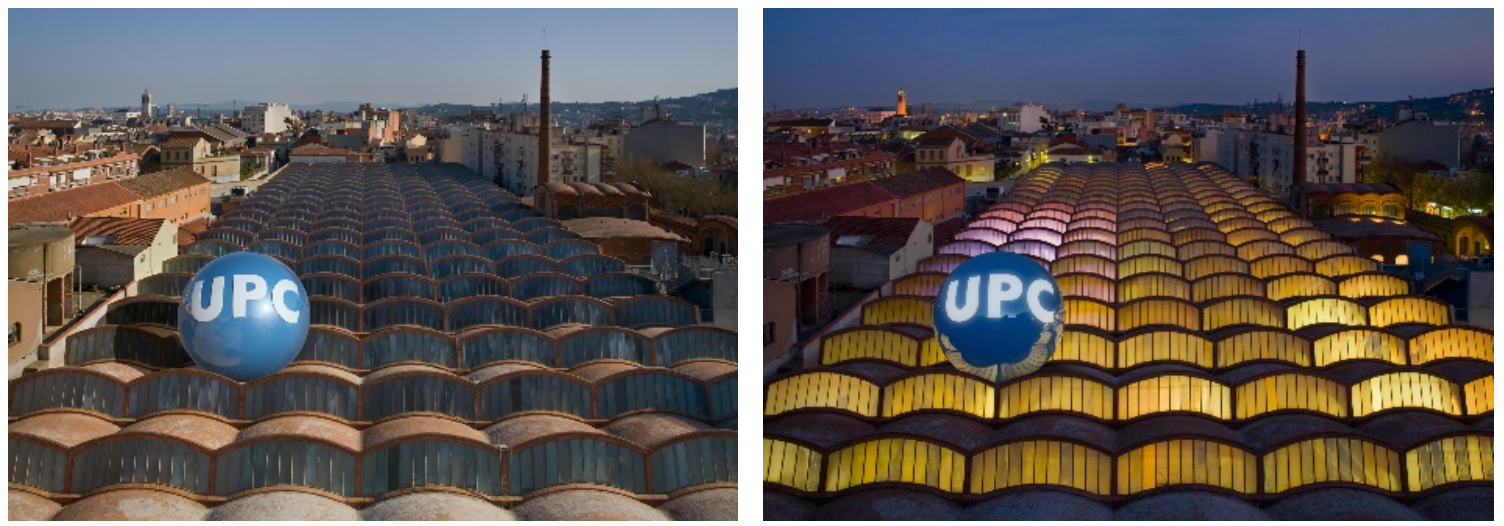

El conjunt de les dues imatges de la il.lustració 6, formen part del final de l'etapa de la maduresa, amb la recerca dels elements essencials entre les imatges del real i del virtual. Exercicis de classe treballats amb un equip intergeneracional, amb la barreja dels coneixements dels $40 \mathrm{i}$ amb la rapidesa del flux de treball dels 20.

Les boles virtuals, com a part del logo de la Universitat Politècnica de Catalunya, serien de grans dimensions en la realitat; uns elements virtuals creats i captats en un ordinador, il.luminats a través dels valors numèrics reals provinents de fotografies.

Un exercici de comunicació visual on estan reflectits la història del patrimoni modernista, les característiques de la llum natural i de la il.luminació artificial, la reproducció d'un espai tridimensional a partir de la geometria de la perspectiva i la quarta dimensió del temps en el pas del dia a la nit. I la utilització d'uns algoritmes matemàtics que han permès la fusió d'unes imatges reals i virtuals en un ordinador. Una fusió d'humanisme i tecnologia, d'art i ciència en un projecte de classe dins l'àmbit educatiu.

\section{Els 60 , un procés de transició cap a la reflexió. La mirada del pre- sent cap al passat}

Els 60 signifiquen l'etapa de la reflexió i una continuació de les il.lusions dels 20. Una etapa per endreçar i arxivar el que ha servit, i de llençar el que ha aportat poc o res en la consolidació de les il.lusions dels 20 o en la maduresa dels 40. 
La capacitat d'adaptabilitat dels 60, conjuntament amb les aportacions dels alumnes de 20 en un aula, és un element clau per consolidar els processos d'aprenentatge al llarg de la vida.

En aquests darrers anys, els alumnes arriben a la universitat, amb l'aprenentatge adquirit a través del sistema educatiu i l'autoaprenentatge après fora d'aquest sistema. Entendre aquesta dualitat de fonts d'aprenentatge ha estat un element clau per organitzar la docència a classe i donar suport a la consolidació de les seves il.lusions.

L'any 2014, Howard Garnerd, amb la col-laboració de Katie Davies, va publicar el Ilibre Generación APP (Gardner i Davies, 2014) on reflexiona sobre com tres generacions diferents es relacionen amb la tecnologia. Garnerd, que va néixer l'any 1950, s'inscriu en la generació que es va formar amb els processos tecnològics analògics, mentre que Katie, tenta anys més jove va començar a veure la introducció dels ordinadors en la seva educació. La germana petita de la Katie, deu anys més jove que ella, ja forma part plenament de la generació de nadius digitals. Tres generacions, tres comportaments diferents davant la disrupció digital.

Des de la reflexió dels 60 es comprova la necessitat d'una aturada en el ritme vertiginós de la recerca del coneixement associat a la tecnologia. La mirada del present cap el futur s'ha d'anar deixant progressivament, als qui encara tenen una mirada cap a un futur professional o docent a llarg termini. Els 60 són un bon moment per reprendre la mirada del passat des del present, amb una visió renovada gràcies els 20 i els 40, i amb les contribucions que han anat aportant any darrera any les generacions més joves.

La mirada del passat des del present és avui una reflexió sobre la comunicació visual de les imatges 2D, 3D i 4D, reals i virtuals, fixes, en moviment i/o interactives. Una reflexió sobre com s'ha viscut la transició de l'analògic al digital, del fotoquímic a la imatge numèrica en el cas de la fotografia. Aquesta reflexió des dels 60 no comporta tampoc deixar de banda la mirada cap al futur. Queden moltes il.lusions dels 20 encara per superar i queden molts aspectes a reflexionar davant una evolució tecnològica que no pararà. Encara que sigui difícil preveure el futur, aquest sempre es comença a dibuixar des del present. «El futur està en el present i en la nostra ment com a projecció del moment científic i social que vivim» (Carbonell, 2007, p. 169).

La comunicació visual canviarà amb l'evolució dels coneixements sobre la fotònica i la informàtica quàntica (Centre de Cultura Contemporània de Barcelona, 2019), uns canvis que afectaran tant als nadius digitals com als transdigitals. Totes aquestes noves evolucions comportaran unes velles i unes noves preguntes a resoldre.

- Quines son les aportacions i reflexions a tenir en compte davant el creixement exponencial de la tecnologia en l'àmbit educatiu?

Les disrupcions que aporta aquest creixement en la tecnologia és cada vegada més visible. Han esdevinguts uns nous tipus d'analfabetisme, unes noves incerteses davant l'excés d'informació, unes noves addicions i uns nous tipus de polaritzacions socials.

Tots els canvis viscuts al llarg de la història han suposat uns avantatges i uns inconvenients per a la societat. Els nous coneixements sempre han comportat que uns individus s'hi adapten i uns altres no puguin o no vulguin adaptar-s'hi, generant uns nous 
«analfabets» o uns nous inadaptats als canvis. Alguns psicòlegs s'han reciclat per enfrontar-se als nous problemes que ha comportat la irrupció de la telefonia mòbil i les dificultats per adaptar-s'hi.

Les plataformes mòbils, principalment les tauletes i els telèfons intel-ligents, han significat una memòria externa a les persones. Un accés ràpid a molts continguts, processos i fórmules matemàtiques. Aquest accés ràpid també significa un excés d'informació, que pot ser negatiu i derivar cap a la desinformació. Noves capacitats d'aprenentatge s'han de treballar en les etapes formatives per poder arribar a una informació contrastada amb el mínim de temps.

Han sorgit unes noves addicions, com per exemple, a uns determinats videojocs. Però el problema, o almenys el problema principal, no està en els jocs electrònics, sinó a la predisposició que tenen uns determinats perfils psicològics a les obsessions per a una determinada matèria, i a la falta d'una anàlisi crítica que reguli determinats dissenys de videojocs. En un camí contrari, els Serious Games aporten millores per a la societat, per exemple, els videojocs per millorar la mobilitat en determinades minusvalideses.

Cada canvi comporta una polarització entre defensors i detractors, no tothom veu les mateixes situacions des de la mateixa perspectiva. Gardner ja parlava en el seu llibre sobre la generació APP, escrit en col-laboració amb Katie Davies (Gardner i Davis, 2014), sobre les dues maneres d'entendre l'evolució digital. Els que anomena com ciberutòpics que veuen el nou paradigma digital com un punt fort i una oportunitat per millorar la societat i, els que anomena com a teòrics escèptics que se centren més en els punts dèbils i els perills que comporta, i que pot comportar aquesta evolució sense fi de la tecnologia.

La fusió entre els diferents punts de vista, i la visió des de diferents perspectives, per arribar a un consens el més ampli possible, és el mètode per avançar en la gestió de nous projectes. La solució, normalment, comporta intentar preveure i minimitzar les reaccions negatives i no recolzar exageradament les reaccions positives.

No interessa que el sistema educatiu estigui polaritzat en favor o en contra de l'evolució tecnològica, s'ha de poder reflexionar i fer projectes amb i sense les TIC. Aquesta evolució tecnològica consolida l'aprenentatge al llarg de la vida, és necessari treballar en les capacitats i els mètodes d'aprenentatge que afavoreixin els alumnes, i els docents, a l'adaptabilitat als canvis continus i saber viure i conviure amb la incertesa.

- L'ensenyament de la filosofia comporta plantejar i resoldre dubtes. Des de la ciència també es fan preguntes i es creen mètodes de resolució de dubtes des de la reflexió humana. Per què no interrelacionar projectes i matèries d'art i ciència en el sistema educatiu?

La geometria i el dibuix en perspectiva i la càmera fotogràfica, són productes de l'evolució de la comunicació visual des d'un punt de vista monocular (Kemp, 2000). Les càmeres cinematogràfiques, i videogràfiques, incorporen d'una forma intrínseca la dimensió del temps, des d'un punt de vista monocular, en la creació de les imatges.

Els estudis sobre el funcionament de l'ull humà i de la visió estereoscòpica en els òrgans de visió, van permetre, des dels orígens de la fotografia, tot un seguit de càmeres i de visors binoculars per reconstruir o simular una visió tridimensional de les imatges.

Tots aquests processos de creació d'imatges parteixen de la interrelació de fonaments artístics i científics, des dels seus inicis i en la seva evolució posterior. 
Reflexions com aquestes han permès crear experiències d'interrelació entre l'art i la ciència en l'àmbit educatiu, com per exemple, les activitats relacionades amb l'espai expositiu «del dibuix a l'art digital» de La Farinera, Centre d'Art Visuals de Vic (La Farinera, Centre d'Arts Visuals de Vic, en línia). Aquestes activitats permeten als infants i als joves observar i experimentar l'evolució dels aparells de perspectiva des del Renaixement a la Pintura Holandesa del segle XVII, i com aquests instruments són els fonaments de la càmera fotogràfica en el segle XIX. Aquestes activitats permeten entendre els canvis en els aparells de creació d'imatges, i l'evolució dels processos industrials analògics cap a la imatge digital, la incorporació de la càmera fotogràfica en els telèfons intel-ligents i els inicis de la Realitat Augmentada. Un espai que permet entendre i experimentar la creació d'imatges com a procés històric, social i cultural, i també una evolució de les ciències, de la tecnologia i de les aplicacions de les matemàtiques, en tots aquests processos. Art i ciència en l'essència més pura, per entendre que la ciència i la tecnologia han evolucionat des de la perspectiva humana, i que aquesta evolució pot estar al servei de la creativitat emocional i de la comunicació entre les persones.

La creativitat i les possibilitats de la Realitat Augmentada és un altre element tecnològic que propicia les relacions entre art i ciència. Generada a partir de la imatge numèrica, amb la interrelació entre imatges reals i virtuals a través d'un telèfon intel-ligent, les seves possibilitats són infinites; tant per les seves aplicacions en l'àmbit social o cultural com en la seva utilització en els projectes docents. El projecte «Ciutats Invisibles» de La Farinera, Centre d'Art Visuals de Vic (La Farinera, Centre d'Arts Visuals de Vic, Ciutats Invisibles, en línia) és un exemple de l'aplicació de la Realitat Augmentada en projectes de divulgació del patrimoni cultural i de divulgació de la història en àmbits educatius. En una de les activitats d'aquest projecte, hi ha marcades al terra les petjades de fotògrafs històrics, $\mathrm{i}$ des d'aquest punt es poden veure les imatges que van realitzar. Amb la Realitat Augmentada es poden contrastar amb la imatge real. La incorporació d'imatges CGI permet veure, amb una estètica realista, les simulacions de construccions arquitectòniques històriques que ja no existeix, o de fets socials o polítics en el mateix espai físic on van passar.

Els projectes de Realitat Augmentada permeten fer visibles, a través de plataformes mòbils, les visions de la ciutat que Italo Calvino narra en Las ciudades invisibles (Calvino, 2011), quan descriu que al passejar per una ciutat històrica es pot imaginar i sentir el que aquells carrers han viscut en el passat. Les possibilitats de comunicació visual que proporciona la Realitat Augmentada aporten, i aportaran, unes noves metodologies per comprendre i divulgar la història. 

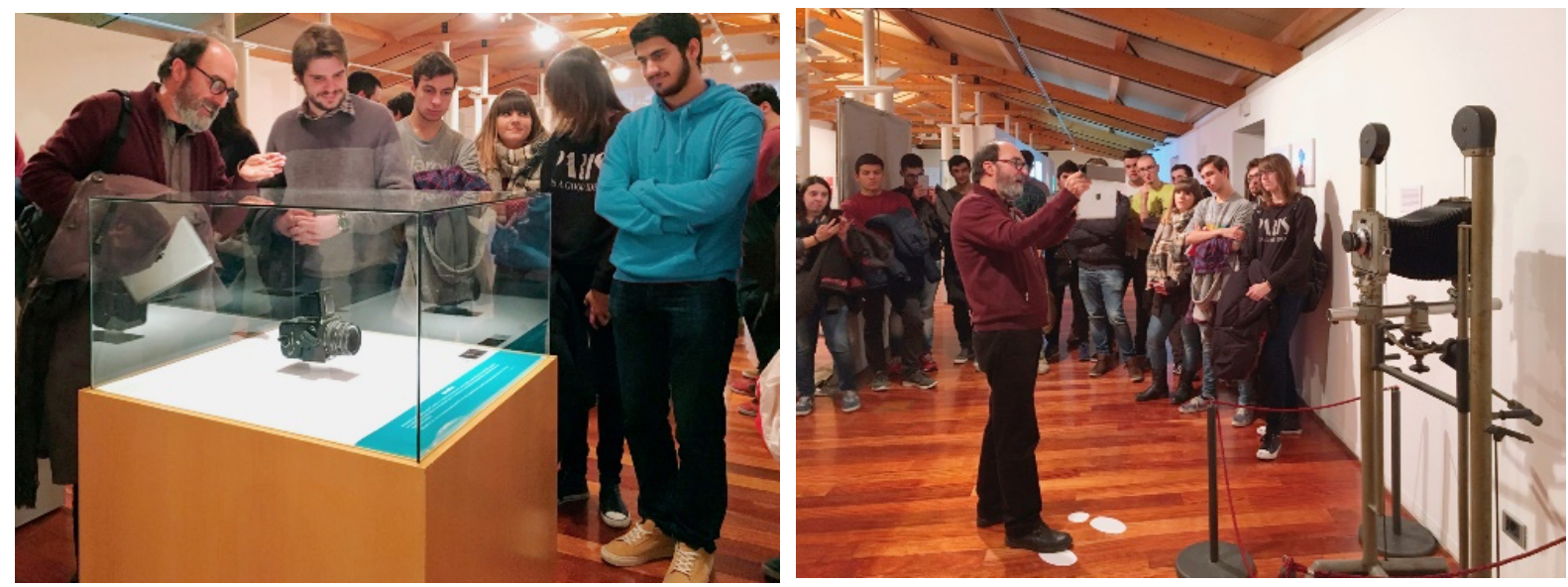

El conjunt de les dues imatges de la il.lustració 7 forma part del final de l'etapa de la reflexió dels 60, amb les aplicacions del sumatori de coneixements d'art i ciència, i amb una interrelació intergeneracional dins i fora de l'aula. Són les fotografies d'una classe que es va fer pels alumnes de Cultura de Visual dels graus del Centre de la Imatge i Tecnologia Multimèdia de la UPC, en motiu de l'exposició «A través del mirall», durant les activitats de Vic Capital de Cultura Catalana de l'any 2016. En l'exposició es podia veure l'evolució dels aparells de perspectiva del Renaixement cap als aparells i les visualitzacions amb Realitat Virtual, passant per les diferents etapes de la fotografia, la cinematografia i la imatge electrònica.

Aquesta activitat expositiva permetia ensenyar als alumnes aparells i eines d'aprenentatge que havien estat utilitzats per alumnes de graus similars en anys anteriors, $i$ ara ja eren peces de museu. Es podia reflexionar sobre com algunes eines de captació d'imatge i de comunicació visual en pocs anys havien quedat obsoletes i com les càmeres fotogràfiques incorporades dins les plataformes mòbils, juntament amb els programaris dels mateixos aparells, podien produir imatges similars. L'alumnat podia comprovar com la Realitat Augmentada servia com a eina docent per explicar, dins l'exposició de forma visual i interactiva, el funcionament d'alguns dels aparells històrics exposats.

Tota una experiència i una evolució històrica viscuda pels més grans, que permetia preveure una evolució encara més ràpida i profunda pels més joves.

\section{La mirada d'elles i ells, el descobriment de les seves il.lusions}

Les il.lusions dels 20 habitualment van lligades al plantejament laboral, sobre que es vol fer i les capacitats i les actituds que es tenen per portar-ho a terme.

L'aprenentatge de la mirada exterior, i de la mirada interior, connota el mestratge de I'anàlisi crítica per entendre els fets del passat i per visualitzar com podrà ser el futur.

On queda la mirada al futur a partir dels 60 ? Si la miréssim des del punt vista purament biològic la resposta seria molt òbvia. Si la mirem des de les il.lusions dels 20 que encara continuen i des de la reflexió del pensament, la resposta també és òbvia, s'ha de reflexionar a partir de les mirades d'elles i d'ells, dels més joves, i com elles i ells encaren el descobriment de les seves il.lusions. 
Aquesta reflexió sobre la mirada dels de 20 és una de les reflexions més interessants del final de l'etapa docent. La principal avantatge dels 60 és el pòsit de més de 40 anys de professió i de reflexió, mentre que els de 20 estan davant de més de 40 anys de futur.

L'actitud intuïtiva és un dels punts forts dels joves, un element important per a la innovació i la cerca de noves idees. Es una de les que es va perdent al llarg del temps, per norma general, i va derivant cap una actitud més deductiva, cap la cerca o l'intent d'apropar-se a la perfecció. L'experiència és una de les avantatges de la maduresa, però no és indispensable en els temps de canvis disruptius.

La innovació tecnològica implica unes habilitats d'aprenentatge que els nadius digitals han après des de la infància, unes capacitats que els transdigitals difícilment podran assolir degut a l'esforç intel.lectual que significa el pas de l'analògic al digital. L'aprenentatge analògic comportava conviure amb uns components més aleatoris i l'aprenentatge digital es fonamenta en uns components més estructurats.

L'evolució cap a estructures professionals i processos d'aprenentatge docent més basats en projectes, significa i comporta unes activitats més flexibles, facilitant la necessitat d'arxivar els processos tecnològics i de gestió obsolets, i la creació de grups de treballs interprofessionals i intergeneracionals.

Els grups interprofessionals permeten ampliar els processos de reflexió i de treball, I'accessibilitat i un millor control dels excessos d'informació. Els grups intergeneracionals permeten sumar les actituds més intuïtives dels més joves amb les actituds més deductives dels més grans. Els grups interprofessionals i intergeneracionals podrien ser un bon model per trencar les barreres establertes en l'educació entre l'art i la ciència.

Tota aquesta evolució cap a estructures professionals i estructures docents basades en projectes, comportarà resoldre altres tipus de dubtes i preguntes.

- L'evolució de la fotònica i de la informàtica quàntica implicarà canvis en les aplicacions de la Física i de les Matemàtiques en la comunicació visual. Quin paper tindran aquestes innovacions en el sistema educatiu?

L'evolució de la informàtica quàntica i la fotònica permeten preveure espais de treballs $\mathrm{nD}$, superant els espais 4D interactius de l'image management actuals (Centre de Cultura Contemporània de Barcelona, 2019). Espais nD difícils d'entendre encara des de les ciències físiques i en canvi perfectament descrits des de l'àlgebra en les matemàtiques.

La millora més evident serà la rapidesa en els algoritmes informàtics, amb l'avantatge que representarà sobre unes determinades matèries i amb els desavantatges que aquesta rapidesa pot comportar en el control de la llibertat individual.

Els avantatges i els inconvenients de tots els processos evolutius al llarg de la història podrien servir de base per intentar comprendre, des de la sociologia i la psicologia, l'afectació dels canvis en el futur.

La comunicació visual fa preveure uns nous recursos visuals, unes noves possibilitats estètiques, socials i amb noves aplicacions docents. Algunes de les aplicacions del futur de la Realitat Augmentada les podem veure, per exemple, en el cas del joc Pokemon Go per a telèfons intel.ligents. Aquest joc ens mostra possibilitats que van més enllà del pur àmbit empresarial i dels components lúdics associats al joc de masses. 
La gamificació de Pokemon Go permet activitats a l'exterior fora de l'espai habitacióordinador, estableix altres usos que poden tenir aplicacions en l'àmbit del treball social i la salut (Infermera Virtual: Pokemon Go: saludable o perillós?, en línia). En l'àmbit de l'educació, per exemple, facilita als nadius digitals l'explicació de I'ús de la càmera fosca utilitzada per Vermeer al segle XVII, començant a fotografiar Pokemons a l'inici de la classe i a partir d'aquí fer una anàlisi crítica de l'evolució de la càmera incorporada al mòbil cap al passat històric.

L'evolució de la informàtica permetrà la restitució en un espai tridimensional de les imatges captades, sense la necessitat de ser visualitzades en una pantalla o ser impreses. Els productes hologràfics són coneguts des dels anys 80 (Musée d'Art Moderne de la Ville de Paris, 1983), i departaments de diferents Universitats estan treballant per trobar-hi noves aplicacions socials i millores tecnològiques ens els processos de creació i visualització d'imatges. Per exemple, el ViRVIG (ViRVIG: Visualització, Realitat Virtual i Interacció Gràfica, en línia) format per membres dels departaments de Ciències de la Computació i de Matemàtiques de la UPC, fan recerca en la modelització, la visualització i la interacció gràfica avançada i la seva aplicació a la realitat virtual.

Els processos de captació de la llum en les càmeres, integrades en un telèfon intel.ligent, permeten tenir en cada punt de la imatge més informació (de les tonalitats clares i fosques $i$, dels espais de color) de la que s'obtenia en els processos fotogràfics de mitjans segle $\mathrm{xx}$. Les tecnologies actuals i els algoritmes informàtics, permeten obtenir informació de cada punt de la imatge, de la distància entre l'objecte i la càmera, i reconstruir informàticament una imatge en 3D amb tota la informació de tons, colors i distàncies, per poder ser visualitzada en una pantalla 2D.

Amb la visualització de les imatges 3D sense la necessitat de les pantalles, el trencament visual anirà molt més enllà que un canvi en les percepcions i la visualització de les imatges, significarà l'evolució de centenars d'anys de captació monocular de les imatges cap a una veritable visualització i comunicació visual amb imatges tridimensionals.

Des de la perspectiva de la comunicació visual en l'àmbit educatiu i en les matèries relacionades amb la cultura visual, ja es pot treballar la visió de la imatge hologràfica partint de l'evolució de la imatge escultòrica al llarg de la història de l'art. L'evolució de la imatge hologràfica des de la perspectiva de l'enginyeria anirà evolucionant amb la millora dels processos tecnològics. Des de la perspectiva humanista de la sociologia i de la psicologia, s'hauria de reflexionar amb més profunditat, els canvis que comportaran aquestes innovacions en la visualització de les imatges tridimensionals.

- L'evolució de la intel-ligència artificial està derivant cap a uns models híbrids amb la incorporació d'elements tecnològics en el cos humà. Què han de dir les reflexions humanístiques davant les previsions que comença a aportar el transhumanisme?

Una de les qüestions a reflexionar sobre el futur és preveure l'evolució del transhumanisme i les seves repercussions. L'evolució dels coneixements sobre la nanotecnologia i la bioquímica fan preveure que la tecnologia ja no serà, només, un element extern al cos humà.

Aquesta visió híbrida amb uns elements tecnològics incorporats en el cos humà fa anys que es tracta principalment des de la ciència ficció. Algunes sèries televisives plantegen el tema del transhumanisme, com per exemple Black Mirror (Netflix: Black Mirror, en línia) des d'una visió més estètica i de ficció i Years and Years (HBO: Years and Years, en 
línia) des d'una ficció més realista i amb un plantejament sobre els dubtes humanístics en què poden repercutir aquestes tecnologies.

No s'hauria d'esperar que aquestes innovacions tecnològiques estiguin en ús per començar a reflexionar sobre els aspectes negatius i els positius que significarà o significaria el transhumanisme.

Si ho mirem des de la perspectiva del coneixement de la fotografia, aquesta va ser un procés evolutiu de més de 2000 anys d'història. Plató ja reflexionava sobre la cambra fosca i no seria fins la revolució industrial que un conjunt d'experiències científiques en física i química, conjuntament amb l'evolució de l'estètica realista, comportarien un canvi en la comunicació visual.

Si reflexionem des del present es pot observar, des de fa anys, que se substitueix el cristal.lí de l'ull humà per una òptica en les operacions de cataractes oculars. Comença a ser habitual que es posin xips a la retina per millorar la visió. Aquest és el cas dels joves que es volen operar la miopia i tenen un cristal.lí molt prim i aquest no es pot reduir molt amb el làser. En aquests casos per millorar la visió sense ulleres, els hi proposen la incorporació d'un xip per no retallar en excés el cristal.lí. En els inicis de la fotografia els estudis sobre l'ull s'incorporaven en el disseny de les òptiques, avui les recerques en òptica i imatge digital es comencen a incorporar en l'ull humà.

En paral-lel als estudis sobre l'ull humà, fa temps que s'està estudiant la transmissió de dades des del cervell a l'ordinador, de moment amb uns casquets experimentals sobre el cap (Centre de Cultura Contemporània de Barcelona, 2019). Avui semblen unes recerques molt primàries i no queda clar el seu èxit, però que passarà amb l'evolució de la informàtica quàntica, amb una gran rapidesa en el processat de dades?

Si ens ho mirem des de la perspectiva històrica, en el segle xVII els estudis de química sobre l'ennegriment de la plata i l'evolució de la càmera fosca anaven per separat. Ningú s'imaginava que en el segle XIX es fusionarien les dues recerques i crearien un canvi en la comunicació visual i en la forma d'entendre la història.

No hi ha cap previsió avui que les millores de visió en l'ull i el moviment de l'ordinador a través del pensament es puguin fusionar. Però comença a haver-hi alguns joves interessats en alguns dels aspectes relacionats amb el transhumanisme, fent recerques i plantejant opcions i idees per a la cultura visual, a partir d'uns híbrids amb elements informàtics incorporats al cos humà.

Des de la reflexió dels 60 podem incidir en la reflexió des del present i en l'estudi de la història des del passat. Podem reflexionar sobre les etapes històriques en què ciència i art anaven units. Podem reflexionar sobre les etapes històriques on s'ha separat art i ciència, i veure que ha comportat un creixement exponencial de la tecnologia, amb una reflexió humanística i ètica que ha anat al darrera i no al costat de la ciència. Però on queden aquestes reflexions davant les il.lusions dels 20 , amb una reflexió de futur a llarg termini?

La fi de la fase laboral ha coincidit amb la pandèmia i el confinament a casa, que ha fet que el final de l'etapa docent fos a través de l'ensenyament presencial en línia. L'ensenyament presencial en línia ha estat una de les grans innovacions en l'educació des de fa anys. 
Algunes plataformes d'ensenyament en línia, com per exemple Adobe Connect, permeten tenir i compartir amb els alumnes una aula virtual i gairebé amb tots els avantatges d'una aula presencial: pissarra virtual, visualització dels materials docents, interacció entre els ordinadors dels alumnes i el del professorat, creació de xats de conversa o de grups de treball connectats, o no, entre ells. L'estructura docent en una classe presencial en directe en línia pot ser molt semblant a la d'una classe presencial en una aula.

Aquest tipus de docència també comporta noves preguntes i una nova manera de resoldre dubtes, amb punts forts i punts dèbils, que s'han d'anar responent i cercant noves solucions. No ha estat sempre aquesta la clau de la reflexió sobre la teoria del coneixement al llarg de la història

II·lustració 8: Pokemon a casa. Fotografia iphone Toni Bover. 2020

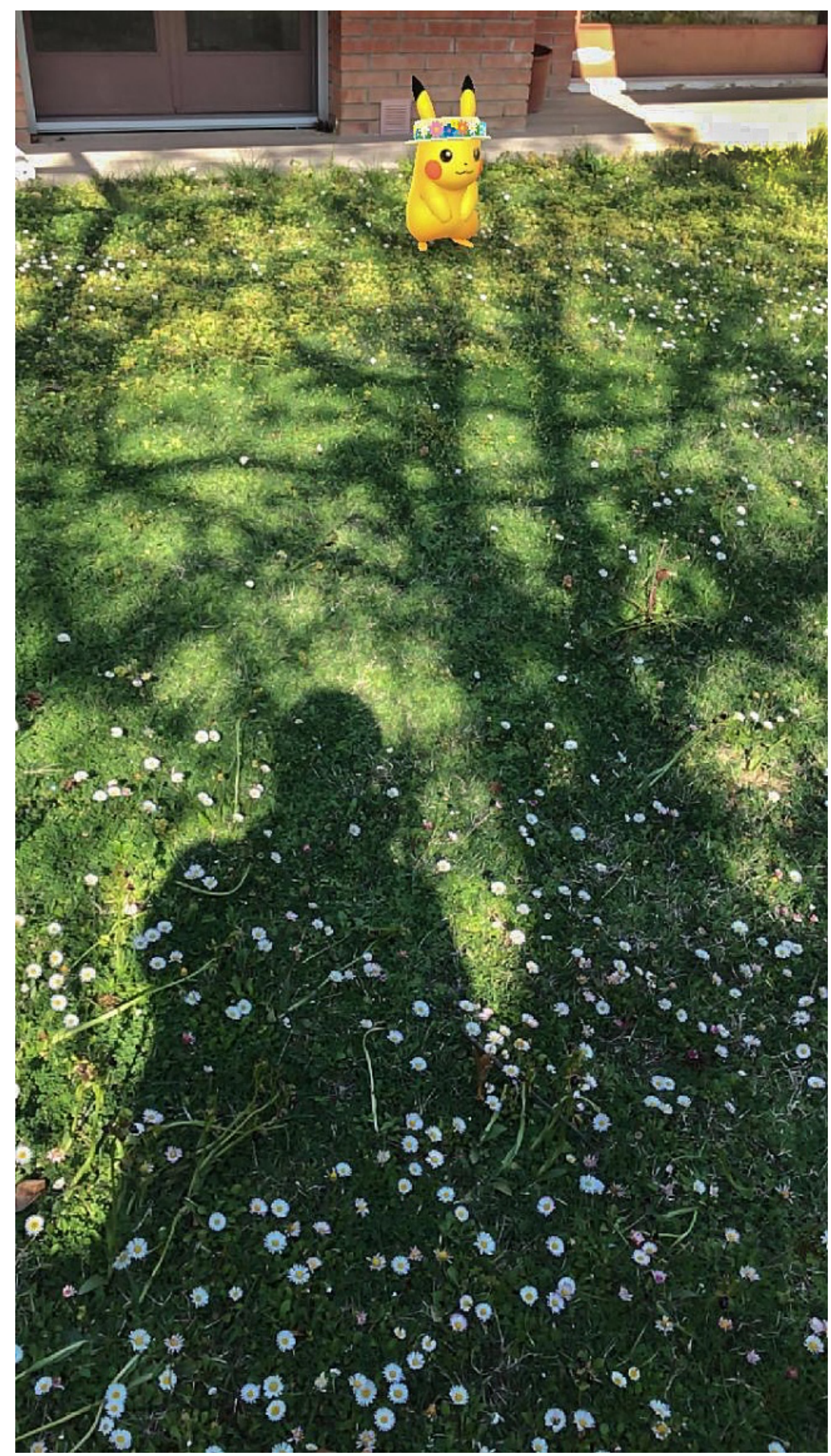




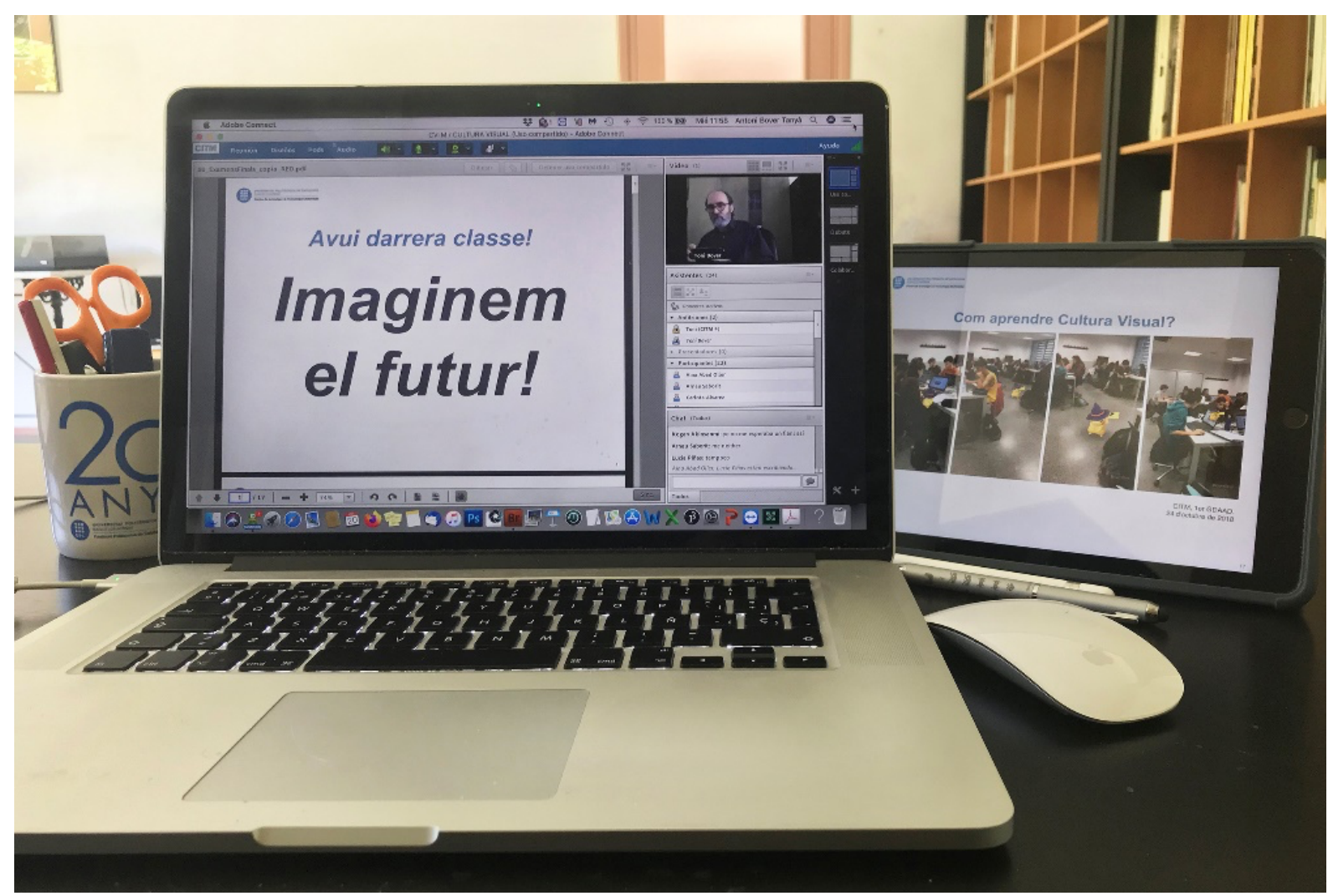

La II.lustració 8 és una imatge captada amb la càmera del mòbil a partir de l'aplicació Pokemon Go. La imatge es va fer per preparar un exercici de cultura visual sobre art i fantasia des de casa, amb la fusió d'elements reals i virtuals, i amb una estètica relacionada amb el realisme. És un dels exemples que es van preparar a partir dels elements propers que es poguessin tenir a casa, per poder interactuar amb els alumnes en una classe presencial en línia durant el confinament.

La Realitat Augmentada del joc està pensada amb un element virtual (les imatges de Pokemons) en continuo moviment dins un espai real, per ser caçat a partir de les habilitats del jugador. En aquest cas la imatge va ser utilitzada per reflexionar sobre l'evolució del concepte de l'Instant decisiu, noranta anys més tard de les reflexions de Cartier Bresson, tots els elements de la imatge havien d'estar ordenats dins l'enquadrament, tenint en compte la cerca del canvi del punt de vista, davant uns elements reals i virtuals en continu moviment.

La il.lustració 9 és una imatge captada amb la càmera del mòbil de la darrera classe presencial en línia de cultura visual. La darrera diapositiva no era només el final de la classe, era per mi, el final de l'etapa laboral

En aquesta darrera sessió de classe vam parlar de cultura visual i de com imaginaven el seu futur professional. Es van manifestar lliurament sobre els seus interessos, alguns relacionats amb la Realitat Virtual, els videojocs, la Realitat Augmentada, les possibilitats de les holografies o el transhumanisme. 
En aquesta darrera classe vam reflexionar sobre la importància que les innovacions tecnològiques no estiguin deslligades de les reflexions humanístiques. I posats a imaginar, que els propers canvis disruptius que elles i ells viuran professionalment, siguin sempre al servei i al benefici de les persones.

Vic, desembre de 2020

\section{Referències}

Barthes, R. (1980) La Chambre Claire: Note sur la photographie. Poitiers, Éditions Gallimard. Baudelaire (1990) Les Flors del Mal. Barcelona, Edhasa Clàssics Moderns.

Baudelaire (1991) Petits poemes en prosa. Barcelona, Edhasa Clàssics Moderns.

Bover, A. (2011) Fotografia d'urbanisme: anàlisi de la imatge fotogràfica en la comunicació visual d'un espai urbà. Regot, J. (Director). Tesi doctoral, Departament d'Expressió Gràfica Arquitectònica, UPC.

Brockman, J. (ed.) (1996) La tercera cultura: Más allá de la revolución científica. Barcelona, Tusquets Editores.

Calvino, I. (2011) Las ciudades invisibles. Madrid, Ediciones Siruela.

Carbonell, E. (2007) El naixement d'una nova consciència. Badalona, Ara Llibres, S.L.

Centre de Cultura Contemporània de Barcelona (ed.) (2019) Quàntica: A la recerca de I'Invisible. Barcelona, CCCB.

Centre National de la Photographie (Ed.) (1983a) Amérique. Les années noires: F.S.A 19351942. Paris, Collection Photo Poche.

Centre National de la Photographie (Ed.) (1983b) Duane Michals. Paris, Collection Photo Poche.

La Farinera, Centre d'Arts Visuals de Vic. [en línia]: Del Dibuix a l'Art Digital. Disponible a: $<$ https://www.lafarinera.cat/index.php?option=com_content\&view=article\&id=93\&lt emid=303\&lang=ca > (Data consulta: 21 de desembre de 2020)

La Farinera, Centre d'Arts Visuals de Vic. [en línia]: Ciutats Invisibles. Disponible a: $<$ https://www.lafarinera.cat/index.php?option=com_content\&view=article\&id=58:c entre-activitats-projectes-ciutats\&catid=27:projectes\&ltemid=254\&lang=ca $>$ (Data consulta: 21 de desembre de 2020)

Fontcuberta, J. (1984) Estética Fotográfica. Selección de textos. Barcelona, Blume.

Fontcuberta, J. (1990) Fotografía. Conceptos y procedimientos. Una propuesta metodológica. Barcelona, Gustavo Gili.

Frizot, M (ed.) (1998) A New History of Photography. Köln, Könemann.

Gardner, H.; Davis, K. (2014) La Generación App: cómo les jóvenes gestionan su identidad, su privacidad y su imaginación en el mundo digital. Barcelona, Paidós.

Gernsheim, H.\&A. (1967) Historia Gráfica de la Fotografía. Barcelona, Ediciones Omega.

HBO. [en línia]: The Handmaid's Tale. Disponible a: <https://es.hboespana.com/series/thehandmaids-tale/6575c701-6c3d-4b14-9d98-

ba67e102dfa1?gclid=CjwKCAjw0On8BRAgEiwAincsHLov2FqBv4kVX_xdnZbS_7kwyFEFVcwfKzkvngbxWNU-jW6d5mO7RoCxw0QAvD_BwE\&gclsrc=aw.ds > (Data consulta: 21 de desembre de 2020) 
HBO. [en línia]: Years and Years. Disponible a: https://es.hboespana.com/series/yearsand-years/bea844e2-bc17-45a3-bae9-

847f2e955aaa?gclid=Cj0KCQjwufn8BRCwARIsAKzP696ikJizszyCmWx5plGskblSh0gJ MdBiBXCen_YC7Y6Pu_8JNSI6mmlaAuKcEALw_wcB\&gclsrc=aw.ds (Data consulta: 21 de desembre de 2020)

Infermera Virtual. [en línia]: Pokemon Go: saludable o perillós?. Disponible a: < https://www.infermeravirtual.com/cat/recursos/noticies/2016/id:954pokemon_go_saludable_o_perillos > (Data consulta: 21 de desembre de 2020)

Keim, J. (1971) La photographie et l'homme: sociologie et psychologie de la photographie. Paris, Castemar.

Kemp, M. (2000) La Ciencia del Arte. La óptica en el arte occidental de Brunelleschi a Seurat. Madrid, Akal Ediciones.

Lemagny J.C.; Rouillé, A. (1986) Historia de la Fotografia. Barcelona, Alcor.

McCloud, S. (2014) Entender el Cómic: El arte invisible. Bilbao, Astiberri.

Musée d'Art Moderne de la Ville de Paris (ed.) (1983) Electra: l'électricité et l'électronique dans l'art au XX siècle. Paris, MAM.

Netflix. [en línia]: Black Mirror. Disponible a: < https://www.netflix.com/es/title/70264888 $>$ (Data consulta: 21 de desembre de 2020)

Scharf, A. (1994) Arte y fotografía. Madrid, Alianza.

Sougez, M.L. (1981) Historia de la Fotografia. Madrid, Ediciones Cátedra.

ViRVIG. [en línia]: Visualització, Realitat Virtual i Interacció Gràfica. Disponible a: < https://www.fib.upc.edu/ca/recerca/grups-de-recerca/virvig-visualitzacio-realitatvirtual-i-interaccio-grafica > (Data consulta: 21 de desembre de 2020)

Zannier, I. (1997) Le Grand Tour. Paris, Canal Éditions. 


\section{0/40/60. Una reflexión iconotextual de la fotografía como arte y ciencia}

Resumen: Los 20 simbolizan la etapa de la ilusión, con la mirada dirigida hacia el futuro. Los 40 abren la etapa de la madurez, con la consolidación de las primeras ilusiones imaginadas desde los 20. Los 60 significan la etapa de la reflexión, con el análisis crítico de las impresiones que ha dejado la fase de la madurez y el recuerdo de las ilusiones de los 20 que aún continúan. Los 20/40/60 no son etapas exactas, depende de las actitudes y de las capacidades de aprendizaje de cada persona. Este artículo es un análisis crítico subjetivo desde el image management y la comunicación visual, y describe cómo estos conceptos han cambiado de una forma exponencial y acelerada durante los últimos 40 años. Las capacidades de análisis crítico y de autoaprendizaje, conjuntamente con la disposición de adaptarse a los cambios, permiten disfrutar de las etapas profesionales y docentes, y son unas habilidades válidas para hacer frente a las fases laboral y post-laboral.

Palabras clave: Arte y ciencia, comunicación visual, fotografía, image management, disrupción tecnológica

\section{0/40/60. Une réflexion iconotextuelle sur la photographie comme art et science}

Résumé : Les années 1920 symbolisent l'étape de l'illusion, avec le regard tourné vers l'avenir. Les années 1940 ouvrent le stade de la maturité, avec la consolidation des premières illusions imaginées depuis les années 1920. Les années 1960 représentent l'étape de la réflexion, avec une analyse critique des empreintes laissées par la maturité et le souvenir des illusions des années 1920 qui perdurent encore. Les 20/40/60 ne sont pas des étapes exactes ; cela dépend des attitudes et des capacités d'apprentissage de chacun. Cet article est une analyse critique subjective du point de vue de l'image management et de la communication visuelle, et décrit comment ces concepts ont évolué de façon exponentielle et vertigineuse au cours de ces 40 dernières années. Les compétences d'analyse critique et d'auto-apprentissage, ainsi que la prédisposition à s'adapter au changement, permettent de profiter des étapes professionnelles et pédagogiques, et sont des compétences valables pour faire face aux étapes professionnelles et post-professionnelles.

Mots-clés : Art et science, communication visuelle, photographie, image management, rupture technologique

\section{0/40/60. An iconotextual reflection on photography as art and science}

Abstract: The 1920s symbolize a time of optimism, looking confidently towards the future. The 1940s are the stage of maturity, with the consolidation of the dreams imagined since the 1920s. The 1960s signify the stage of reflection, with the critical analysis of the impressions that the stage of maturity has left and the memory of the dreams of the 1920s that still continue. 20/40/60 are not exact stages: they depend on the attitudes and learning abilities of each person. This article is a subjective critical analysis from the perspective of image management and visual communication, and describes how these concepts have changed exponentially and rapidly over the past 40 years. Critical analysis and self-learning abilities, together with the predisposition to adapt to change, allow us to enjoy the professional and teaching stages, and are valid skills for approaching the work and post-work stages as well.

Keywords: Art and science, visual communication, photography, image management, technological disruption 